\title{
Properly identified imaginary needs, an inaccurately proposed methodology: The case of Rochester school of accountancy's positive accounting methodology
}

\author{
Khalid Al-Adeem ${ }^{1}$ \\ Faculty of accounting at King Saud University, Saudi Arabia
}

\begin{abstract}
Research Question: Whether accounting research has been in a better status after the domination of Rochester School of Accountancy's Positive Accounting Methodology.
\end{abstract}

Motivation: This study revisits the debate of the validity of Rochester school of accountancy's positive methodology. Rochester school of accountancy's positive accounting research has properly identified the assumed imaginary need of the US market. While positive accounting methodology may not be scientific under various accounts for science, it has contributed to accounting methodologically.

Idea: Restricting financial accounting on issues related to decision-usefulness and perceiving corporate reporting as a product of accounting choices from an agency theory perspective constrains other dimensions of reality. Any restrictions to definitions of the role of accounting and its function (Glauter \& Underdowen, 1974) blocks profoundly deep-rooted in contextual factors such as a country's social, political, and economic environment that all make up

\footnotetext{
${ }^{1}$ Corresponding author: Associate professor of accounting and Director of Research Center at King Saud University, Saudi Arabia. kra3@case.edu; kaladeem@ksu.edu.sa; khalidlaldeem@gmail.com; +966540518179

I thank many academics for responding to my emails while collecting material and information about material for this manuscript. I thank Dr. Gary Previts, A Professor at Case Western Reserve University, UAS; Dr. Ray Ball, A Professor at the University of Chicago, USA; Dr. Richard Laughlin, Emeritus Professor of Accounting at King's University, UK.; Dr. Thomas Dyckman, Professor Emeritus at Cornell and Adjunct Professor at Florida Gulf Coast University; Dr. Volkova, Olga, Associate Professor at National Research University Higher School of Economics, Saint-Petersburg, Russia; and Dr. George Jones, Associate Professor at Case Western Reserve University, USA. I acknowledge the comments of the two anonymous reviewers. All remaining errors are my own.
} 
accounting which supposedly needs to be considered (Hellmann et al., 2010) in properly theorizing comprehensively practiced accounting.

Data: Extensive writings have that documented internationally throughout time have been looked over.

Tools: An analytical and critical examination has been conducted upon internationally accounting literature in a wide-ranging manner to provide an evaluation regarding Rochester school of accountancy's positive accounting research.

Findings: The positive accounting methodology of the Rochester school of accountancy has been criticized by several accounting researchers for decades and even deem it disappointment and probably shame. Yet, Watts and Zimmerman declared themselves prime candidates. Its prevalence is the rhetoric of scientific inquiry. A measure of the failure of the so-called positive accounting methodology has achieved lays in its inability to become universal because differences in institutional environments persevere in the world

Contribution: Revisiting the debate of the validity of Rochester school of accountancy's positive methodology potentially contributes to our knowledge in assessing its legitimate prevalence in academic accounting research. New accounting researchers and scholars need to be aware of the predominant theoretical structure that governs the empirical financial paradigm and its limitation. This is especially significant to accounting researcher who has been intellectually trained under the positivistic tradition of economics.

Keywords: Rochester School of Accountancy; Positive Accounting, Accounting Research, Research Methodology; Accounting Education; Rhetoric; Science; Theorizing, Theorization; Accounting Theory; Paradigm; Domination; Elitism; Role of Accounting.

\section{JEL Codes: M14; M41; M42; M48}

\section{Introduction}

Theories are on-demand to explain observed systematic behavior (a phenomenon). Without an adequate understanding of the identified phenomenon, predicting their behaviors may forever be impossible - different modes of reasoning yield specific types of theatrical explanations, e.g., theories. Similar to the epistemological and ontological divergence in establishing understanding about the universe and universal laws that govern perceived reality, offered explanations about an observed phenomenon differ methodologically [1] depending on the assumptions underlying such methodologies of inquiry employed in carrying our investigations.

In their work, accountants and accounting theorists have primarily employed two modes of reasoning to develop and structure their proposed accounting theories (e.g., Ijiri, 1975; Schroeder et al., 2010; Wolk et al., 2004). The first type is normative: this type prescribes the contents that should be reporting and that ought to be 
Properly identified imaginary needs, an inaccurately proposed methodology:

The case of Rochester school of accountancy's positive accounting methodology

measuring corporate performance. The second type is the positive type of theorization: this type describes the content of corporate reporting as it is.

Both modes of reasoning have been put in place in accounting to prescribe or describe the contents of corporate reporting. None of the proposed accounting theories has gained widespread acceptance thus far (Al-Adeem, 2017a, 2017b, 2017c; 2019a, 2019b; Al-Adeem \& Fogarty, 2010; Al-Hazzani \& Al-Adeem, 2020; American Accounting Association Committee on Concepts and Standards for Externals Financial Reports, 1977; Beaver, 2002; Belkaoui, 2004; Chatfield, 1977; Coetsee, 2010; Gaffikin, 1987; García, 2017; King, 2006; Lee, 2009) nor a philosophy of its own (Gaffikin, 1987; Ijiri, 1967). Indeed, theorizing corporation as a model for conducting business where ownership and management are divorced (Berle \& Means, 1932) epitomizes a lasting challenge to accounting since the emergence of a corporation as an acceptable form of conducting business contributing to an economy (Al-Adeem, 2017a; Al-Adeem \& Fogarty, 2010; AlHazzani \& Al-Adeem, 2020; Merino, 1993; Previts \& Merino, 1998).

Accounting research witnessed a wave of empiricism in the late sixties after the publication of Ball and Brown (1968) and Beaver (1968) [2]. The emphasis on empirical accounting research may have been triggered by two reports published in the late fifties on the state of academic accounting research, among other factors. Notably, Gordon \& Howell's (1959) report was sponsored by The Ford Foundation, while the Carnegie Corporation sponsored Pierson's (1959) report.

After executing empirical research in accounting in a mechanistic fashion (Wolk et al., 2004) for a decade, Watts (1977) demonstrates that accounting research does not provide an explanation based on hypothesis testing as to why corporate reports are the way they are despite being based on finance presuppositions and conjectures [3]. An agency-based theory [4] for financial statements facilitates the development of political and market interactions (Watts, 1977). Watts and Zimmerman (1978) further explain that the choice among accounting procedures permitted under accounting standards can maximize managers' utility. Guided by agency theory, observed behavior in financial literature can be labeled positive theorization from financial accounting research to distinguish it from prescriptive accounting research (Watts \& Zimmerman, 1978). In the following year, another study (Watts \& Zimmerman, 1979) illustrates the superiority of their view in comparison to other normative theories that are, according to them, best-deemed apologies for policymakers. The demand for accounting theories in a regulated economy is the demand for justification-excuses (Watts \& Zimmerman, 1979, p. 286). A large part of their works (Watts \& Zimmerman, 1981, 1982, 1983, 1986, 1990) have continued to publicize their research methodology in academic accounting research at the expense of no lesser importance than questions for the development of accounting and in operating its role in society. "Interest in...contribution to the accounting discipline was giving way to capital market research, led by (among others) the 
Universities of Rochester and Chicago," which represents an unfortunate shift in the development of accounting thought (Persson, 2016: xix).

This paper sheds light on the possibility that Rochester School of Accountancy's positive accounting research has identified the imaginary needs of the US market despite the possibility that the proposed methodology of Rochester School of Accountancy may still be inaccurate, especially when generalization is globally is attempted. This study intends to achieve two objectives. First, this study aims to revisit the debate of the validity of Rochester School of Accountancy's positive methodology. Such an exploration potentially contributes to our knowledge in assessing its legitimacy. Second, current and new accounting researchers and scholars need to be aware of the predominant theoretical structure that governs the empirical financial paradigm and its limitation. This is especially significant to accounting researcher who has been intellectually trained under the positivistic tradition of economics.

The remaining of the paper is organized as follows. Section 2 presents a short survey of Rochester School of Accountancy's methodology. Section 3 details where Rochester School of Accountancy might identify the imaginary needs of participants in the US capital market. Such needs exist when users exist but are not made up or imagined. Section 4 discusses the extent to which under which definition of the term paradigm Rochester School of Accountancy' positive accounting methodology represents a paradigm. Section 5 judges positive accounting research of Rochester School of Accountancy and addresses what intellectually we have harvested. Section 6 summarizes the study and concludes that serving the current needs of members of a society in a changing environment, where corporate scandals expose ethics erosion, needs to be addressed and fulfilled when theorizing corporate accounting. Not all the answers are laid down and can be found by economic traditions.

\section{Rochester school of accountancy: A Short survey of its methodology}

Newly-organized universities tend to imitate the prevailing 'mother' university (MacGregor 2008 as cited in Cloete et al., 2015). Christenson (1983 as cited in Williams, 1985: 310) refers to the "Rochester School of Accounting" whose origins are traced to Chicago School Orthodoxy (see Chabrak \& Burrowes, 2006) where ideas of neoclassical economics dedicate other ideologies (Whitley, 1988). Williams (1985: 310) affirms, "Rochester may not be a new school in terms of the history of ideas as much as a branch office of rather old schools." Neoclassical economics, namely positive economics, it is claimed, has been prevalent in normative and valueladen approaches and methodologies in economics (Friedman, 1953). 
Properly identified imaginary needs, an inaccurately proposed methodology:

The case of Rochester school of accountancy's positive accounting methodology

Professor Ross Watts and Professor Jerold Zimmerman have based their view of the firm on the agency as a meta-theory guiding empirical accounting research launched a decade before proposing their so-called theory to assist in interpreting empirically attempted accounting research (see Watts \& Zimmerman, 1986). Employing the positive type of theorization, Findlay and Williams (1987) argue that agency problems can be utilized to revise taken for granted theoretical structure grounded in the neoclassical valuation paradigm in finance.

Agency theory as ideology (Hunt III \& Hogler, 1990) has spread in the US accounting academe and some parts of the world to become a legitimate meta-theory to the extent of which accounting doctoral programs are by, and large founded in the US (Al-Adeem, 2017b; see also Reiter, 1998) and possibly elsewhere in the world (see Al-Adeem, forthcoming) adopt it. For example, positive accounting methodology is manifested in the African continent (Ndjetcheu, 2012). The presence of African students may not be significant in magnitude in, most notably elite, American universities. Unlike the prospect of the spillover influence of the Rochester School of Accountancy on students from Africa, Asian students have attended several American universities, including elite ones. Some of them went back home to disseminate what they learned and to establish accounting doctoral programs in their home country to teach what they learned to breed, intentionally or unintentionally, more local positivists. Ironically, accounting academics in Africa promote positive accounting methodology (see, for example, Ibraheem, 2002), evaluate it (Ibraheem, 2008), analyze it (Yousof, 2006), and compare it to other research methodologies (Othamn, 2000)[5]. They even supervised doctoral dissertations and master theses on the value of positive research and its contribution to the development of the accounting profession in their societies (e.g., Adbulahakam, 2008). In addition to its spread by doctoral education, agency theory dictates the accounting publishing market in the US and becomes a nonnegotiable theoretical structure in top-tier accounting journals (see Al-Adeem, 2019b; Jeanjean \& Ramirez; 2009; Volkova, 2018).

Watts \& Zimmerman have positioned their proposed methodology on the proposition that since "[r]ationals differ...across accounting standards because a standard is the result of political action" (1979: 287), "...the nature of accounting theory changes as political issues change. Accounting theory will change contemporaneously with or lag political issues. We will not observe accounting theory generally leading political action" (Watts \& Zimmerman, 1979: 288 emphases in original). Watts \& Zimmerman (1979, p. 288) further articulate that

"If political transactions costs are high so that there is a demand for excuses which are useful weapons in the political arena, if the demand for accounting theory is dominated by the demand for excuses, and if demand determines production, accounting theories will be generated by, not generate political debates." 
Therefore, the demand for accounting theory from the perspective of Watts \& Zimmerman is to rationalize and provide excuses for policymakers. In their words, "The most useful theories for persuading uninformed voters are theories with stated objectives appealing to those voters, e.g., the "public interest." As a result, individuals demand normative accounting theories, which make prescriptions based on the "public interest" (Watts \& Zimmerman, 1979: 275).

Watts \& Zimmerman perceive "accounting theory as an economic good" where its role is to "examine the nature of the demand for the supply of that good" (1979: 274275 emphases added). Accounting research's initial task is to form accounting theory. An imperative fragment of accounting theory is resultant from the research progression (Wolk et al., 2004). Academic accounting journals have been established and sponsored by accounting academics to develop accounting theory (Chatfield, 1975; Flesher, 1991; Zeff, 1966). Such attempts continued until the academic accounting research paradigm in the US has shifted to the financialempirical archival (Al-Adeem, 2017b; 2019b; Al-Adeem \& Fogarty, 2010; see also Hopwood, 2007).

However, similar to other disciples of Chicago, neoclassical economics that Watts \& Zimmerman depended on in their attempts to theorize practiced accounting makes their contribution to accounting theory "modest in their aims and focus on how particular social processes helped to produce particular sets of practices in certain circumstances" (Whitley, 1988: 639-640). Positive accounting methodology may not be scientific under Popper's account for science (Mouck, 1990) as well as, according to (Kabir, 2010), under the remained standard interpretations of sciences, namely Kuhn (1996) and Lakatos (1970). Yet, Watts and Zimmerman (1990 as cited in Tinker and Puxty 1995: 10) defended their theory choice, arguing that since accounting academics are utilizing it, they passed the market test, and their choice must be suitable for academic accounting researchers. However, Boland and Gordon (1992) contend that it fails the test of rooting to economics-based. In addition, several accounting researchers worldwide have criticized the prevalence of positive accounting research programs and methodology (Al-Adeem, 2017b; 2019b; 2019c; Al-Adeem \& Fogarty, 2010; Avelé, 2014; Belkaoui 1996; Boland \& Gordon, 1992; Chabrak, 2005; Chabrak \& Burrowes, 2006; Chambers, 1993; Christenson, 1983; Hines, 1988; Kabalski, 2016; Kaplan \& Ruland, 1991; Kabir, 2010; Lowe et al.,1983; Major, 2017; Milne, 2002; Mouck, 1989, 1990, 1992; Ndjetcheu, 2012; Okcabol \& Tinker 1990; Sterling, 1990; Sy \& Tinker, 2009. 2011; Tinker, 1988; Tinker et al., 1982; Persson, 2016; Tinker \& Puxty 1995; Sinha, 2008; Srivastava \& Baag, 2020; West, 2003; Whitley, 1988; Williams, 1989, 2003, 2017; Whittington, 1987) and its dominance to competing for abstract construction mostly institutional theory that can theoretically expound observed phenomena in accounting (Collin et al., 2009). Some have explained such a prevalence by imposition (Al-Adeem \& Fogarty, 2010, Al-Adeem, 2017a,b, Al-Adeem; 2019b) because shifting doctrines in a discipline and superiority of a latter paradigm to its ancestors is an ordain by an 
Properly identified imaginary needs, an inaccurately proposed methodology:

The case of Rochester school of accountancy's positive accounting methodology

authority in a scientific community (Chalmers, 1999; Kuhn 1996; see also Feyerabend; 2010).

\section{Meeting imaginary needs of participants in the US capital market}

Chatfield (1977: 4) states, "There seem to be certain perennial demands which every developed society makes on its accounting records." Studying the development of the accounting thought to 1900 , Littleton (1933/1981, p. 361) condemns that accounting is progressive where the phenomena forming the subject matter are continuously altering. The American economy, which is characterized by corporate domination, is one of the largest economies in the world. While the corporate model first emerged in Great Britain, where the South Sea Company was formed in 1711 (see Previts \& Merino, 1998: 24; Al-Hazani \& Al-Adeem, 2020), it flourished in the United States.

The separation between management and ownership characterizes this model of doing business (Berle \& Means, 1932), wherein theorizing the firm as a form for doing business has been a confounding task for accounting and accounting researchers alike (Al-Adeem, 2017a; Al-Adeem \& Fogarty, 2010; Merino, 1993; Previts \& Merino, 1998). Taking into consideration the external parties' needs in the corporate reporting function has been a challenging undertaking. A variety of efforts have been attempted by academic organizations, e.g., the American Accounting Association (AAA) $(1936 ; 1941 ; 1957 ; 1966 ; 1971 ; 1971)$ to overcome such a challenge. Professional bodies, e.g., the American Institute for Certified Public Accountants (AICPA), commissioned and sponsored several studies, for example, Sanders et al., (1938)[6]; Moonitz (1961); Sprouse and Moonitz (1962); Staff of the Accounting Research Division. (1963); Grady (1965) have contributed to addressing such a challenge. Accounting theorists have contributed their thoughts and exerted serious energies in addressing the issue faced by corporations. Cole, (1908); Dickinson, (1914), Esquerre, Paul-Joseph, (1914), Hatfield, (1909), Kester, (1916), Montgomery, (1912), Sprague, (1907), Wildman, (1913), Alexander, (1950), Canning, (1929), Chambers, (1966), Edwards and Bell (1969), Gilman, (1939), Ijiri, (1975) Littleton, ( 1933; 1953), MacNeal, (1939), May, (1943), Paton, (1922), Paton \& Littleton (1940), Preinreich (1996)[7]; Sterling, (1970), and Sweeney, (1936) have attempted a variety of ways to overcome the issue of reporting to external parties who have interests about internal corporate affairs that affect the financial position and corporate performance. Table (1) lists some of their work. 


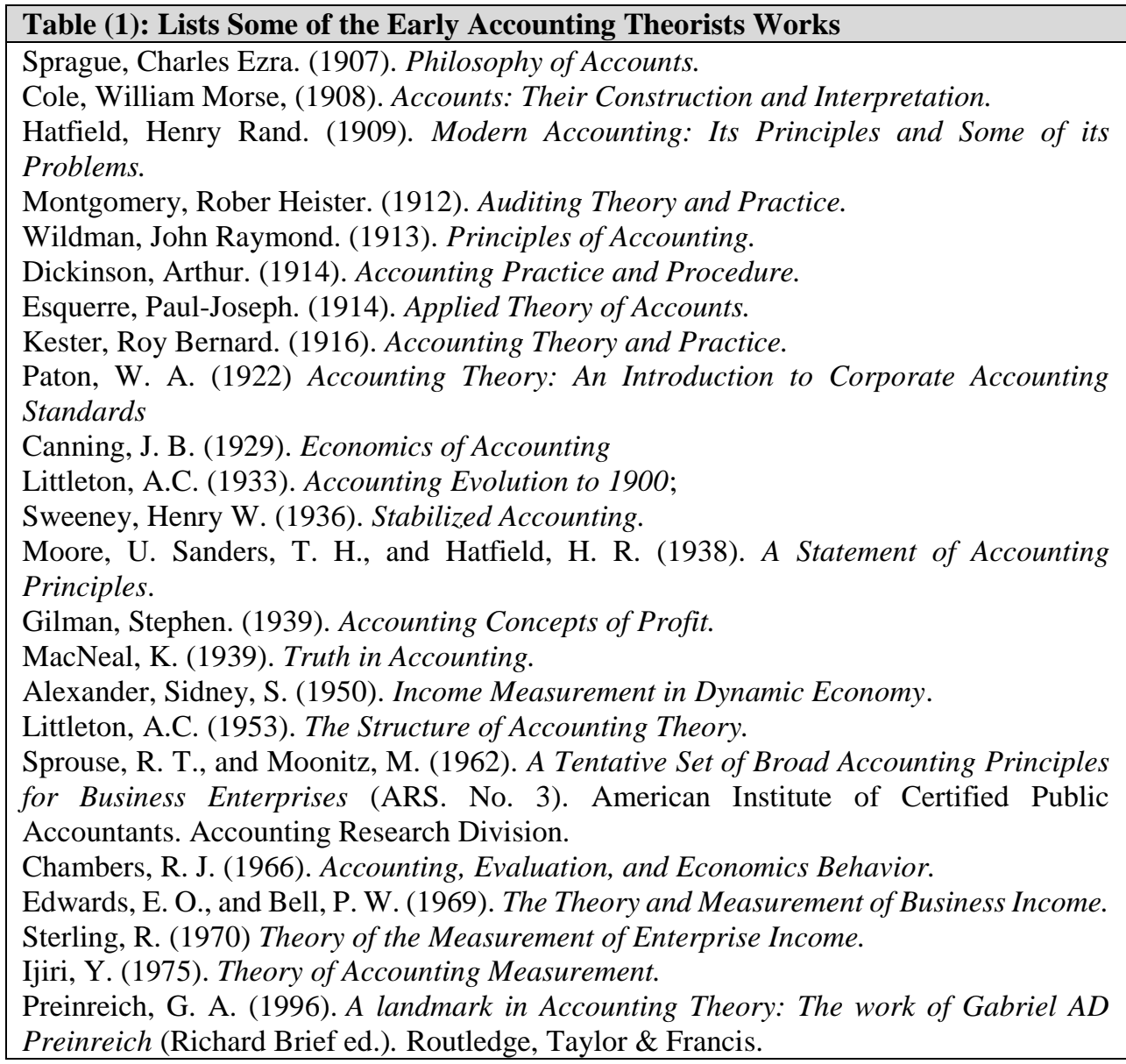

The efforts of accounting theorists can be virtually divided into broad categories. The first one was led by early accounting educators who may not necessarily obtain formal doctoral education (see Statement on Accounting Theory and Theory Acceptance (SATTA), 1977, s. 6). One of their central attempts was to describe accounting as practiced for college students learning to account after accounting became a major in colleges and universities for students to learn [8].

The second regime represents formal attempts to theorize practiced accounting. The era of formally conceptualized and framing accounting practices started with Paton's seminal work, which was originally the doctoral dissertation he finished in 1920 that was awarded in economics (SATTA, 1977, p. 6) and later published in 1922 (see Zeff, 1999). Previts (1980) labels the period of the development accounting thought prior to 1920 as "pre-classical" which started in 1900.

Littleton (1933/1981, p.361) asserts that older devices become lesser operative when conditions are alerted; Littleton further argues that earlier ideas become irrelevant 
Properly identified imaginary needs, an inaccurately proposed methodology:

The case of Rochester school of accountancy's positive accounting methodology

when new problems urge surrounding conditions to invoke fresh ideas and inspire clever researchers to advise new methods. Such a conjecture is to be applied to evaluate positive accounting methodology and assess whether the circumstances surrounding accounting have alerted due to the advancement of the US market. Such development in the capital markets was in conjunction with attempts for the normatively theorizing corporation. Like accounting that evolves in response to business needs (Cowan 1968; Scott 1926; Chatfield 1977, Hopwood, 1987; Littleton 1933/1981), accounting theory evolves as a response to changes in the market (Quinn, 2014). Watts \& Zimmerman (1986, p. 7) observe that accounting theorists have become "sought to prescribe the contents of accounting reports" after the Securities Acts were passed." They articulately add:

"Partners in accounting firms, bureaucrats in government agencies and corporate managers will seek out accounting researchers who have eloquently and consistently advocated a particular practice which happens to be in the practitioner's, bureaucrat's, or manager's selfinterest and will appoint the researcher as a consultant, or expert witness, or commission him to conduct a study of that accounting problem." (Watts \& Zimmerman, 1979, p. 287)

During an era when the normative mode of theorization dominates accounting thought, managers of corporations argue for the legitimacy and suitability of methods and procedures to process financial transactions. By considering the effect of lobbying of individuals created by government regulation, arguably no single theory has been accepted (see Watts \& Zimmerman 1979, 1986, 1990). Perceiving normative theorists and methodologies as functional justification in the political lobbying and prescribed accounting theorization as a concern with "public interest", Watts \& Zimmerman (1979, p. 275) illustrate that:

"The most useful theories for persuading uninformed voters are theories with stated objectives appealing to those voters, e.g., the "public interest." As a result, individuals demand normative accounting theories which make prescriptions based on the "public interest."... the demand is for rationales or excuses. Because it arises from the political process, the demand for normative, "public interest'-oriented accounting theories depends on the extent of the government's role in the economy."

Put differently, rather than normalizing the content of annual reports. Accounting theory needs to be constructed positively in the sense that it is "capable of explaining the factors determining the extant accounting literature, predicting how the research will change as the underlying factors change, and explaining the role of theories in the determination of accounting standards. It is not normative or prescriptive" (Watts \& Zimmerman, 1979, p. 274). A procedure must "employ materials of investigation and adopt attitudes of inquiry comparable to those used by the successful sciences" to be considered positive (Bentley, 1939, p. 473). 
The methodology of Watts \& Zimmerman was concerned with the corporate management utility function (Watts \& Zimmerman, 1978). That is, "management's utility is a positive function of the expected compensation in future periods (or wealth) and a negative function of the dispersion of future compensation (or wealth)" (Watts and Zimmerman, 1978, p. 113). Opining that accounting should view corporations from the firm's standpoint where the nexus of relationships can be considered contractually, Watts \& Zimmerman (1978) posit that factors that motivate managements to influence accounting standards can be identified.

Watts \& Zimmerman aim at explaining corporate accounting where management's preference of financial accounting affects the content of presentation of the corporate reporting. Because participants in the market value annually announced financial statements (Ball and Brown, 1968; Beaver, 1968), Watts \& Zimmerman probably have identified the need of participants in the capital markets. Such participants are aware of the corporate executive management's ability in determining financial accounting standards choices in the preparation of financial statements. Watts \& Zimmerman (1979, p.278) view

"Capital market participants contract to supply capital. Managers and owners seeking capital have incentives to enter into contracts that limit the agency costs they incur. But these contracts must then be monitored and enforced since managers have incentives to circumvent the contracts...Thus, contracts will reduce agency costs only if they include provisions for monitoring. Since audited financial statements are useful devices to monitor these voluntary agreements between owners and managers, these statements serve a useful role in the capital markets and owner-managers will agree to provide them in advance."

Viewing the interaction in a corporation as an agency issue, Watts \& Zimmerman (1978) accept that since accounting offers choices to managers, such choices affect the efficiency of corporations. Given that accounting numbers are used in contracts such as the managers' compensation plan, managers have incentives in choosing how accounting offers how to treat such financial transactions. Like production methods, a firm organizes its financial policy, and accounting methods form part of the technology the manager uses to produce the firm products (Watts and Zimmerman, 1990, p. 135). Hence, "[a]ccounting plays a role in these systems and so appears to be part of the firm's efficient contracting technology" (Watts \& Zimmerman, 1990, s. 135). Nasution et al. (2020) further aver that positive accounting methodology is always a proportion of accounting research and one of the foundations of management's choices concerning accounting procedures to exhaust the possibilities of their best interest.

Summing up, acknowledging the need for a theory to guide empirical research (Dopuch, 1979; Kothari, 2001), with the lack of a theory in accounting from its own to guide research, the revolution of financial accounting research (Beaver, 1998) has 
called for the need to found empirical archival accounting research on abstract structure. Agency theory supplemented the revolution of financial accounting research (see Reiter, 1998) as a meta-theory. Asserting that "positive theory of standard-setting to understand management incentives," Watts and Zimmerman's (1978: 113) methodology curtails the role of accounting theorization. The positive type of theorization and methodology that Watts \& Zimmerman propose is the most controversial in the history of accounting theory (Avelé, 2014).

Rochester School of Accountancy is to promote the needs of economies with such a controversial theoretical structure. Absence shareholders or passive owners characterize the American corporate economy. Theoretically, passive ownership is reconciled with conventionally economic reasoning of private property rights (Merino, 1993: 169). In reality, they are presumably weak in comparison to managers (Roe, 1996) and left to the discretion of external auditors who are supposedly influential and powerful if the standards and the legislative rules related to the subject matter are "unambiguous," (Gibbins et al., 2001: 539). Audited financial statements are ultimately the result of joint efforts of managers and their auditors (Antle \& Nalebuff 1991; Gibbins et al., 2001). While managers are incentivized to apply accounting standards selectively, auditors assume the duty to force them to report objectively (Watts \& Zimmerman, 1979 as cited in Hackenbrack \& Nelson, 1996). However, an auditor may not be fully independent (Reiter \& Williams, 2004), which, in turn, compromises the audit function in the corporate model for monitoring executive management (Al-Adeem, 2015; Al-Adeem, forthcoming; see also Conway, 2020).

While normative theorists predominantly contribute theories to resolve issues resulting from the separation between management and ownership, Watts and Zimmerman view the dilemma facing financial accounting of reporting corporate performance and effects of externals and internal affairs on the financial position and to external parties from a behavioral standpoint. What motivates managers to choose selected accounting treatments or procedures that accounting standards permit? The determination of accounting standards can be conjectured in a positivistic term (Watts \& Zimmerman, 1978). "The main purpose of positive accounting theory...is being able to explain and predict accounting practices, associated with individual behavior in choosing accounting methods that can maximize their utility" (Nasution et al., 2020). Its dependency on the rationality assumption of the investor is present (Srivastava \& Baag, 2020). Participants in the capital market may benefit more by knowing what motivates executive management to report a certain way and being aware of managers' underlying behavior to account and report for certain transactions and circumstances. Such understanding enhances capital market participants' ability to decide particular behavior rationale. Contemporary empirical research (e.g., Cohen et al., 2007; Holthausen, 1990; Sun \& Rath, 2008) has demonstrated that opportunistic managers always seek alternatives accounting standards only when such a standard is vogue concerning the treatment aimed by managers. 
Intended users of financial statements are hypothetically, but not actually, constructed (Young, 2006: 596). Their choices of information have been normatively molded and hence decided (Young, 2006: 596). Arguably investor decision usefulness and hence objectives of financial reporting has been decided by views of FASB individual board members (Nurnberg, 2015). Standard-setting bodies have constructed an image of rational economic decision-makers for financial statement users (Young, 2006: 596). Decision-usefulness has been narrowly defined (Nurnberg, 2015; see also Horgans, 1981) and recently been rethought (Williams \& Ravenscroft, 2015). Hence, it is safe to conclude that the decision-usefulness method of the standard setters may not lead to proper theory formation (Coetsee, 2010). Furthermore, it perpetuates the notion that shareholder value-maximization is a sort of myth (Stout, 2012; Stevelman, 2013; Weinstein, 2013). An exclusive aim of accounting on parties financing its operation, namely shareholders and debt holders, does not entitle the profession to full redemption of its responsibility toward other parties who have stakes and interests in a corporation (Shearer, 2002). FASB's approach in constructing reality has been under attack (Lee, 2006a, 2006b; Macintosh, 2006; Mattessich, 2009; Williams, 2006). Contemporary accounting scandals, including big corporations, have questioned financial report's trustworthiness (Schiehll et al., 2007).

Schiehll et al. (2007, p. 89) hence advise "researchers in financial accounting...to be aware of the many dimensions and realities that they are attempting to "account for" and represent." Similarly, Belkaoui (2004: 352) observes that "[t]he bureaucratic intellectual is reduced to being an 'ideology' because... [a researcher] subordinates or abandons the research for a universally comprehensive understanding of social, cultural and physical reality." Adding to this is the limited accounting literature on users (Laughlin \& Puxty, 1981).

\section{Positive accounting methodology's scholarly potential as a paradigm}

SATTA (1977) concluded that two perspectives of the theoretical development exist in accounting: the evolution way and revolution form to conceptualize the progress of accounting thought. SATTA (1977: 41) suggests that if the former viewpoint were valid in accounting, then "we need only to continue the collective struggle to adapt and modify our theoretical structure as environmental changes occur." While "[t]he evolutionary view of accounting theory formation has considerable appeal... the accounting literature of the past decade or two appears inconsistent with the evolutionary view of accounting theory development" (SATTA, 1977: 41). Attempting to explain the discourse over accepting financial accounting theory, SATTA applies Kuhn's theory of the 'revolutionary structure of science' to accounting, treating each proposed theoretical approach that SATTA considers a distinct paradigm. While SATTA acknowledges the potential validity of the 
application of Kuhnian view to accounting, the Committee on Concepts and Standards for External Financial Reports, who prepared SATTA, expressed sensitivity in applying Kuhn's view to explain the state of theory acceptance in accounting (SATTA, 1977: 41, footnote 1). SATTA concedes that other viewpoints, such as Lakatos, might be considered for explaining the development of accounting theory (1977: 41 footnote 1; p.42 footnote 2).

Meanwhile, Kabir (2010) discusses that positive accounting methodology comprises elements of all the three standard accounts of sciences, namely, Popper (1959), Kuhn (1996), and Lakatos (1970), but none of them has the necessary support to a methodologically position itself nor does it scientifically stand. Mouck (1990) asserts that positive accounting methodology fails to meet Popper's criteria and Laktos' count of science. Whether to apply Kuhn's argument to the development of accounting thought is debatable among accounting writers, and there is no consensus on an unambiguous answer as yet.

Mouck (1993), among others, has relied upon Kuhn count in explaining the changes in the development of accounting thought. Cushing also (1989: 6-7) discusses attempts made by accounting writers who had applied Kuhnian interpretation to illustrate the development of and categorize accounting thought. From 1966 to 2006, "62 articles that made reference to the work of...Kuhn were identified, concentrated into 16 international and national journals" (Beuren \& de Souza, 2011: 87). Wells (1976) stresses that Kuhn is a good framework for understanding the development of accounting thought if it is applied. Wells (1976: 480) stated, "If the analogy presented...is correct, i.e., if Kuhn's notion of a revolution can be applied to accounting..."

On the other hand, Laughlin (1981) argues that "Kuhn's theory" does not explain the progression of accounting. Kuhn (1996), in his book, refers to natural science and not to other forms of scholarly. Arguably, if Kuhn's theory applied to non-science, paradigms have to exist in a discipline for his theory of revolution to be applicable and his interpretation to be utilized. In the case of accounting, those, who apply Kuhn's interoperation, refer to different sets of paradigms. For example, Butterworth and Falk (1986, as cited in Cushing 1989, p. 8) deem valuation and stewardship two different paradigms. SATTA considers the theoretical approaches: 1) the perspective mode of reasoning, 2) the descriptive mode of reasoning, and 3) decision-usefulness, included in SATTA as competing paradigms. Belkaoui (2004, ch. 10) expands the list to six paradigms. Al-Adeem and Fogarty (2010) differentiate between the conventional and empirical archival paradigms currently dominating US academic accounting research. However, Cushing (1989: 34) argues, "If the double-entry bookkeeping system is the basis of accounting's current paradigm, then presumably a new paradigm would not be based on double entry." Hence, in Kuhn's terminology, accounting may lack the state of multiple paradigms. The term paradigm refers to "A general perspective or way of thinking that reflects fundamental beliefs and assumptions about the nature of organizations" (Kuhn, 1970, as cited in Gioia \& Pitre, 1990; Lincoln, 1990, as cited in Gioia and Pitre, 1990). 
Bricker (2006) considers social sciences in the stage of a pre-paradigmatic phase of their development. "'[S]ciences' are generally more progressive than the 'nonscience'" (Laaudon, 1981: 153). Similar to other social sciences that may be deemed in the pre-paradigmatic phase of their development, the interpretation, which SATTA of the paradigm uses as a shared and taken-for-granted belief among accounting researchers, is to justify the nonexistence of an accepted accounting financial theory, can be rejected. Carduff (2010) used the term "model" among other terms in inquiring about the shift from the stewardship model in corporate reporting to the contract model by analyzing the annual report of the US Steel from 1901 until 2006.

Professor Kathleen Wells (2005; see also Belkaoui, 2004: 335-336) revealed that Kuhn used the term paradigm thirty different times in his book, The Structure of Scientific Revolution. Utilizing Kuhnian interpretation and relying on philosopher Larry Laudan (1981), Cushing (1989: 10) ensures that the application of Kuhn's concepts can be extended to other forms of intellectual inquiry, namely accounting. Other definitions of the term of paradigm that Kuhn employed, such as methodology, can justify the predominance of positive accounting methodology in accounting research. Accordingly, debated and proposed approaches to developing accounting theory can all be viewed as a single paradigm constructed on a double-entry bookkeeping system. Such lines of thinking possibly differ methodologically but certainly do not represent divergent worldviews for accounting. Previts (1984: 4) asserts that,

"Kuhn's thesis controversial because they allege, it slips into an uncritical relativistic mold, much remains to favor the original notion of a "paradigm" as a tool useful for historical categorization. In part, it is not tainted by our prior meanings and lends itself to "schools of thought" structures. "Schools" in the history of thought are not new. It is a well-established vehicle in economic history but has been less critically employed in the history of accounting thought."

The Rochester School of Accountancy's research program has contributed to accounting methodologically. Vatter (1947: 1) asserted that "Every science, methodology, or other body of knowledge is oriented to conceptual structure - a pattern of ideas brought together to form a consistent whole or a frame of reference to which is related the operational content of that field." After the publication of Ball and Brown (1968) and Beaver (1968) and the efforts by accounting researchers who were promoting empirical research in accounting needed to have it enclosed in a framework and a theoretical structure that guides it and helps in designing empirical studies (see Dopuch, 1979: 67) and interpreting its empirical analysis and findings (see Kothari, 2001: 106). Even though positive accounting methodology neither has an element of theory (e.g. Christenson, 1983; Demski, 1988; Gaffikkin, 1988; Hines, 1988; Mouck, 1989; Sterling, 1990; Tinker, 1988; Tinker et al., 1982; Whitley, 1988; Whittington, 1987) nor logic (Williams, 1989), it serves as a meta-theory for the 
Properly identified imaginary needs, an inaccurately proposed methodology:

The case of Rochester school of accountancy's positive accounting methodology

newly launched stream of accounting research. If the positive methodology of The Rochester School of Accountancy were absent, empirical financial research might have probably remained unfeeling. Although accounting has emerged from practice (Hopwood, 1987; Sterling, 1977; Vatter, 1947), it has always been founded on a structure of ideas that provide rational descriptions for particular ways and means (Chatfield, 1977). Accounting practice is based on methodology (Vatter, 1947: 1). Hence, the development of accounting requires a study of the balance between methodology and constituent (Bedford, 1965: 2).

Watts \& Zimmerman have offered a relatively different conceptual approach to accounting research that, according to Petruk et al., (2013: 53), has influenced the development of accounting theory the progression of its standardization. Accounting and the reporting function of accounting in the corporate model are the focus of their proposed methodology on corporate accounting. To what extent their view suits other models of doing business remains, however, unanswered. The label of their conceptualized model theoretical and methodological attempt should be reflecting the aim of their methodology's limitations. About agency issues and costs in the illustration of their view of the accounting standardization process, Watts \& Zimmerman cited Jensen and Meckling (1976). They stress that "....agency costs arise in any situation involving cooperative effort (such as the co-authoring of... [the] paper [referring to their paper they were authoring]) by two or more people even though there is no clear cut principal-agent relationship" (Jensen \& Meckling, 1976: 309). Issues of cost and agency exist in family-owned enterprises (Schulze et al., 2001). Other organizations are not impervious to agency issues as well (Fama and Jensen, 1983). Whether the Rochester School of Accountancy's methodology explains and predicts practiced accounting in other forms of conducting business, e.g., sole proprietorship and partnership, may virtually remain unexplored.

\section{Judging positive accounting research of the Rochester school of accountancy: What intellectually has been harvested?}

Like the impossibility of capturing economic reality in corporate reporting (White et al., 2003), contemporary accounting researchers' claimed ability to capture economic reality underlying corporation is generally impossible (Al-Adeem, 2017b). Kabir (2010, p. 145) reports that positive accounting theory proponents are silent on issues such as: how to decide rationally whether to consider a new theory? At what stage the criterion of greater explanatory power should be applied to choose from among competing theories? How to choose from among two theories when the phenomena explained by one theory are not a subset of the phenomena explained by the other? Furthermore, using "advanced mathematical models and statistical tests", researchers in positive accounting traditions, as a matter of course, analyze "interrelations between fragments of reality" (Kabaiski, 2016: 71). "One can be 
impressed by the mathematical and statistical apparatus in such an article, but after a moment, one is faced with the question: That is correct, but what do we get from it?" (Kabaiski, 2016: 71; emphases in original).

In his speech at The SAXE Lecture in Accounting in 1983[9], Professor Ross Watts compared two of the University of Chicago Conferences on Empirical Research in 1967 and 1982. Watts (1983) was not sure about whether the result of "economicsbased accounting research" caused the reduction in the participation of accounting practitioners who will, he speculated, join accounting academics meeting if such results "provide a better explanation for accounting practice." He nonetheless expressed satisfaction that accounting has gained the respect of economists. Tinker (1985) applies Keynes' remark (1936: 383 as cited in Tinker 1985: 111) that "every practical person, who feels that he is free of intellectual influences, is usually the slave of some defunct economist", to some accountants. In the same vein, Reiter and Williams (2002: 591) observe that accounting academia positioned accounting in a "subservient" status quo to economics. Is accounting's role to function up to the economists' expectations, or has yet another noble and novel role in society? Were early accounting academics, who worked on segregating the American Accounting Association (AAA), which The American Association of University Instructors in Accounting (AAUIA) was at that time to become in 1935 the AAA, from the American Economic Association in 1923 (Zeff, 1966: 19-20) right? Not only early doctorates awarded accounting academics were in economics conspicuously Hatfield and Paton, but also "several of the most prominent writers, notably Canning and Alexander, were economists" (SATTA, 1977: 6-8). If economics is the proper umbrella of accounting in doctoral education, then why accounting doctoral education was progressed to be offered under the umbrella of commerce and business administration (see SATTA, 1977; Zeff 1966)? Suppose economics were the proper tent for conceptualizing accounting practice and aiding accounting research. Would it not be logically suitable for early accounting academics, educators, and practitioners not to separate it from seeking and affirm its autonomy?

Positive accounting traditions jeopardize accounting autonomy as a distinct discipline. Financial empirical accounting research, or the "new empirical paradigm" that Dopuch (1979: 67-68) labels, gives the impression to be accompanied by a loss of the accounting discipline independence (Jeanjean \& Ramirez, 2009). Accounting research should not be based on theories from other disciplines, namely finance and economics (Coetsee, 2010). The excessive dependence on economics and finance has led to some accounting researchers spot no dissimilarity between accounting and economics (Williams, 2000).

The suitableness of agency as a meta-theory for studying and addressing accounting and corporate-related issues may not be helpful while observing phenomena and exhaustiveness in studying them. Because positive accounting methodology fails to effectively link the multiple parties with contradictory interests of the firm 
(Ndjetcheu, 2012: 35), from the firm's stakeholder perspective, the utility of positive research methodology may be grossly inadequate. Agency theory fails to extrapolate accounting regulation advancement rooted in rationality assumption (Kaplan \& Ruland, 1991). Positive accounting research, which was founded on agency theory, "failed to recognize the social and organizational entrenchment of accounting for lack of overture" (Chabrak, 2005: 701-702). For example, "the positive-accountingbased social disclosures literature fails to provide distinct arguments for selfinterested managers' wealth maximizing" (Milne, 2002: 370). Some researchers recently argue for two versions of agency theory: the positivist and principal-agent versions (Osho \& Ayorinde, 2018: 6-7). While "the agency problem can be solved by prescribing the appropriate governance mechanisms to limit the agent's opportunistic behavior," the latter is concerned with "describing the mechanisms that solve the agency problem" (Osho \& Ayorinde, 2018: 7).

After a decade of the first article Toward Positive Accounting Theory appeared in 1978 and approximately two years after the publication of Watts and Zimmerman' Positive Accounting Theory (1986), several accounting researchers have articulated their views on Watts and Zimmerman's works concerning the status of accounting research after it transitioned to so-called scientific research (e.g., Demski, 1988; Hines, 1988; Mouck, 1989; Gaffikkin, 1988; Tinker, 1988). Watts and Zimmerman's (1979) proposed methodology is justified when only accepting "'Truth'... [as] ultimately a social construction, not an absolute, epistemic one" (Tinker \& Puxty, 1995: 11). The presumption that the truth underlying so-called scientific accounting research can be recognized by only appealing to data limits or even preventing vision and awareness of values masking facts (Tinker, 1988: 183).

Watts and Zimmerman's positive research methodology is best described as inadequate because it is founded on unrealistic rhetoric of perfect markets (Demski, 1988). In addition to the fact that accounting lacks a positive structure ( $\mathrm{Yu}, 1976$ ), accounting numbers may or may not represent phenomena (Sterling, 1988). While accounting numbers place of interest traits of enterprise reality are quantitatively measurable and assembled into the accounting structure, they intermittently neglect dimensions of firm reality that are not quantifiable in this manner (Schiehll et al., 2007). Empiricism is not restricted to numbers simply because our experiences are not limited to numbers (Sorter, 1979). The development of the preeminent theory or the methodology occurs due to penetrating arguments, open-handed in arrears value to the others' perspectives and understanding (Sinha, 2008).

In addition, positive theories remain value-laden that they typically disguise an oldfashioned ideological prejudice in their accounting policy allegations (Tinker et al., 1982: 167). "All theories, scientific or otherwise, are subject alike to empirical and conceptual constraints" (Laudon, 1981: 153). While Watts and Zimmerman (1979) degrade early accounting theorists by labeling them apologists, their so-called positive accounting research program is a continuation of the body of knowledge 
erected by early proprietary theorists [10]. The so-called positive accounting theory remains an apology in style (Tinker, 1988). The perceived cataloging between normative and positive theories in accounting discomfits the profession due to the embeddedness of ideological traits in accounting theory (Tinker, 1988: 183). A normative framework that tolerates empirically determined means-end premises integrated into normative theories to fit real-world practical science criteria is always available in accounting (Mattessich, 1996). Hence, the development of accounting is attainable with the utility of becoming what it ought to be (Hopwood, 1987). At any given time, normative accounting theory, which serves society's needs, can be developed (Al-Adeem \& Fogarty, 2010). The normative approach in accounting is promising (Yu, 1976), and normative accounting standard is possible (Chambers, 1976). Some accounting scholars concluded that "the positivistic nature of mainstream accounting research is not the only acceptable research methodology for accounting research" (Coetsee, 2010: 14).

Moreover, debatably, since "...neither positive nor normative research (in its absence) has created a comprehensive theory of accounting" to date, the more modern view to developing accounting is through a combination of both normative and positivistic approaches (Coetsee, 2010: 13). In this regard, Laudone (1981: 153) argues, "there is no fundamental difference in kind between science and other forms of intellectual inquiry." Consequently, the segregation between science and nonscience that Watts and Zimmerman establish (Mouck, 1992: 54) limits the dialog to individuals on one side of the discrimination line (McCoskey 1985: 26 as cited in Mouck 1992: 54). Accounting researchers who are proficient in the positive traditions may find literature in the development of accounting thought as a journey in 'the land of wonder' (Al-Adeem, 2019c: 422). Contemporary accounting researchers, mainly in the US, are unaware of the wisdom inscribed by accounting intellectuals from the 1920s through the 1960s (Granof \& Zeff, 2008). The institutionalization of contemporary positive accounting traditions of researchers inhibits their ability to comprehend the accounting literature early accounting scholars initiated (García, 2018: 217). Major (2017: 178) decides, "discussing questions of an exclusively theoretical and methodological nature contributes nothing to the desired advancement."

Inexorably, the competition among theorists, especially those who subscribe to different camps in the same field of knowledge, is ongoing. Since "each side argues from a different paradigm with different rules and no common ground," no single theory is to be accepted (Watts \& Zimmerman, 1990: 149; see also SATTA, 1977). Watts \& Zimmerman acknowledge that concerning methodology is a "no-win" situation (Watts \& Zimmerman, 1990: 149). Disciplines and fields of knowledge never close their doors of being out of business due to reaching the ultimate theory governing their professions. 
Properly identified imaginary needs, an inaccurately proposed methodology:

The case of Rochester school of accountancy's positive accounting methodology

Paradoxically, despite the fundamental flaw in their economics-based research methodology (Watts \& Zimmerman, 1990: 147) that other researchers have also identified (e.g., Christenson, 1983; Demski, 1988; Gaffikin, 1988; Hines, 1988; Mouck, 1989; Sterling, 1990; Tinker, 1988; Tinker et al., 1982; Whitley, 1988; Whittington, 1987), Watts and Zimmerman exhibited the courage to pronounce themselves as front-runners (Mouck, 1992: 54). Logically, if the state in which attempts for theorizing practiced corporate accounting fits the description portrayed by Watts and Zimmerman $(1979,1986,1990)$, why should an intellectual individual be convinced by reasons that Watts and Zimmerman offered in their criticisms and attempt to weaken normative accounting conceptualization of practiced corporate accounting? Succinctly put, why may such reasons not apply to the Rochester School of Accountancy's research methodology? Would not their suggested methodology or theory be an excuse that the market demanded, and this should justify the claimed receipt by others to their methodology or theory (Tinker \& Putxy, 1995: 10)? The positive accounting methodology of the Rochester School of Accountancy is the most criticized in the history of the development of accounting thought (Avelé, 2014), is a true failure (see Kaplan \& Ruland, 1991; Milan, 2002), and is an embarrassment (Tinker \& Puxty, 1995: 7). The widespread utilization of their research program among researchers may not signify the validity of their theoryselection (see Tinker \& Puxty 1995). Watts and Zimmerman may have utilized market-based strategy as a defensive mechanism to publicizing their work. Whitley (1988: 643) asserts,

"Given the way the academic career system operates in the USA, it seems probable that they will be successful even though their analysis is seriously flawed and relies on theories of a scientific method that are incoherent and inapplicable to accounting research."

Their contribution is rhetoric rather than methodological (Boland \& Gordon, 1992). "The Rochester School has successfully used the rhetoric of scientific inquiry to exploit a general infatuation with 'scientific; research in US business School" (Mouch, 1992: 54).

What Watts and Zimmerman utilize in their competition for theory domination cannot be deemed winning because not all promoters of the proposed theories subscribe to a single paradigm or share a common background. Only when academics control their discipline can they force their dogma (see Chalmers, 1999; Kuhn, 1996; Whitley, 2000). The popularity of positive accounting methodology is attributed to imposition but not to its usefulness (Al-Adeem \& Fogarty, 2010; AlAdeem, 2017b). Through standardizing doctoral education (Al-Adeem, 2017b; Reiter, 1998) as well as colonizing doctoral programs in accounting with values underlying positive methodology (Whitley, 1988: 643), accounting journal editors efforts to cease the contributions of normative theorization in accounting outlet (see Dopuch, 1979) [11], and controlling editorial board of top-tier journals (Al-Adeem, 2009b), Watts and Zimmerman's research methodology has spread. Eminent 
commentators on Watts and Zimmerman were prohibited from publishing their stories in scholarly journals (Tinker \& Puxty, 1995; see also Williams, 2001). Means employed in spreading the Rochester School of Accountancy's ideology in accounting research could be a story of success that is justified by Machiavellianism [12] or a Machiavellian mask where outcomes justify the means, but certainly not to the foundation of science by an appeal to its utility or an added value to accounting practice and accounting thought. Professor Stuipta Basu, a Rochester graduate who, among other achievements, has printed his name in the top US accounting and economics journals, argues that modern accounting inquiry, regulation, and delivered education are habitually premised on unscientific ideology (2015). If "[i]t is shameful that we still cannot answer basic questions" (Basu, 2012: 865), then the question becomes as follows: what have we been accomplished since 1978? Professor Basu is a product of Rochester School of Accountancy. His biography [13] at Temple University reads as "Sudipta earned his $\mathrm{PhD}$ and MS at the University of Rochester." His biography also testifies that six of his manuscripts were published in the Journal of Accounting and Economics, one of which won the 2012 AAA Distinguished Contribution to Accounting Literature Award. We experienced the same episode in the late 1970s when Watts and Zimmerman criticized the schism between accounting research and practice and won the AAA Distinguished Contribution to Accounting Literature Award for their 1979 paper, which is probably the most controversial publication in the history of accounting (see Tinker \& Puxty, 1995). When a product of an accounting school has made a call that is oriented to view accounting phenomena from a financial standpoint, making innovations in accounting research by turning the focus away from financial economics (see Basu, 2012) indeed elicits attention. However, whether we bear witnesses of a new wave of intellectual transition remains uncertain.

Shifting the focus of an academic community mandates an appeal to an authority of the discipline. An academy can be sociologically conceptualized where participants seek domination to assure that their values and dogma dictate others' (Kuhn, 1996) and their kind is reproduced (see Whitely, 2000) to sustain the existence of their species. Accounting as a field of knowledge is no exception from such a phenomenon. Its elites promulgate their shared ideology (e.g. Al-Adeem, 2017b, 2019b; Fogarty, 2011; Fogarty \& Jonas. 2010. Fogarty \& Jonas; Fogarty \& Liao, 2009; Fogarty \& Zimmerman, 2019; Lee, 1995, 1997; 1999, 2001; Lee, Guthrie, \& Gray, 1998; Lee \& Williams, 1999; Rodgers \& Williams, 1996; Williams, 2001, 2017; Williams \& Rodgers, 1995; see also Heck \& Jensen. 2001; Tinker \& Puxty 1995; Tuttle \& Dillard, 2007). "Accounting is therefore both a stake and an instrument in a constant struggle for symbolic domination" (Farjaudon \& Morales, 2013: 157). The accounting academe becomes a stultifying, dogmatic, methodologically driven system, mainly to harvest doctrinally correct academic statuses (Williams, 2017). 
Properly identified imaginary needs, an inaccurately proposed methodology:

The case of Rochester school of accountancy's positive accounting methodology

\section{Summary and concluding remarks}

The comparison that Watts and Zimmerman initiated in 1979 to market their methodological perception of a suitable approach toward a theorization of corporate accounting was unnecessary. Their paper published in 1978 extended Watts's (1974; 1977) perspective about corporate reporting and the firm. In their following work (Watts and Zimmerman, 1979), they have presented their proposed methodology in a way that is competing and superior to prior accounting theorization that was normative in a mode of reasoning. Several accounting researchers and scholars (Christenson, 1983; Demski, 1988; Gaffikkin, 1988; Hines, 1988; Mouck, 1989; Sterling, 1990; Tinker, 1988; Tinker et al., 1982; Whitley, 1988; Williams, 1989; Whittington, 1987) reviewed their works including their notable and most probably complete version of their so-called theory, the positive methodology, compiled in their Positive Accounting Theory (1986) book. While the presentation of their methodology (theory) in a book-length should notionally be a complete presentation and illustration of their methodology, researchers still found it unsound. Following the publication of their book, Watts \& Zimmerman (1990) acknowledged putting forward a flawed work in their Ten Years Perspective paper but still declared victory.

Early replies of Watts and Zimmerman to comments, critiques, and criticism on their work were not rooted in a well-grounded and appealing theoretical foundation (Tinker \& Puxty, 1995)[14]. In the beginning, they even do not appear to understand how their proposed methodology is faulty (Watts \& Zimmerman, 1990). They stated, "...economics-based research methodology may be fundamentally flawed in ways we do not now understand" (Watts \& Zimmerman, 1990: 147). Watts (1983) interpreted Popper's (1995) count of science, arguing that there was no normal significance level for hypothesis testing such as the universally used 5 or 10 percent level of significance. Accordingly, in the absence of better theories, Watts (1983) argues that a 20 percent level of significance could be acceptable because the choice always exists between imperfect theories or between an imperfect theory and no theory at all. It will be ironic to observe the reaction of scholars, researchers, and academics in other fields of knowledge, including economics, when accounting researchers fail to reject null hypotheses at above 10 percent level of significance. What claims of knowledge that is eligible for addition to the body of accounting knowledge with a 20 percent chance that the phenomenon is due to chance [15].

A measure of the failure of the so-called positive accounting methodology has achieved lays in its inability to become global because differences in institutional environments persevere in the world. The ascendency of the positive theory turns into less conspicuous in the middle of the 1990s, especially under the deployment of globalization processes, resulting in a significant number of counterexamples, which led to criticism of the positive theory (Petruk et al., 2013: 52). The institutional environments of accounting and time restrict the generalizability of positive accounting methodology (Kabir, 2010: 145) in Africa (Ndjetcheu, 2012). 
Accounting academics who got their doctoral education and training in the US elite ones that predominately subscribe to the so-called positive methodology went home to do research or operate doctoral programs in the same way he/she experienced while working on his/her doctorate (see Al-Adeem, 2017b, 2019b). Accounting doctoral students in the positive methodologically orientated programs are arguably trained to be (Al-Adeem, 2019b) but are not necessarily true believers (see Reiter, 1998). They were kept over time reminded the value of accounting numbers and the first published manuscript on the topic (Ball \& Brown, 2013; 2019; Brown 1989) and of articles subscribed to the empirical paradigm (Ball, 1971).

Accounting education is crucial in bringing the two arms (practice and academe) together and supplying accountants with what they need to perform their accounting effectively. The academic arm of accounting is to produce research that guides practiced accounting and solves emerging issues accounting practitioners face.

Accounting as a field of knowledge and a profession rests on the accounting research-practice-education triangle (see Kaplan, 1989). These three arms of accounting must operate collectively in an effective and efficient mechanism so that the benefits are accrued not just to the accounting discipline but also the accounting profession (see Foster, 1988; Grebe \& Odendaal; 2017; Inanga \& Schneider, 2005; Lee, 1989; Kaplan, 1989; Sterling 1973). The schism among these three arms or between any two of them already exists (Bloom et al., 1994; Bricker \& Previts, 1990; Bricker, 1993), leading to dysfunctionality in the accounting establishment. For example, a gap between accounting research and public policy (Rutherford; 2011; Singleton-Green, 2010) may result from dysfunctionality in the research-practiceeducation triangle.

It is imperative to learn the lessons. Dealing theoretically from an accounting perspective with complex problems society faces should not be through simplifying factors and affecting them under the veneer of parsimony to fit them in abstract models that may not be conceptualized enough to mirror complex realities (see Lowe et al., 1983) of business and the environment in which it operates. An accounting methodology that hinges on and is narrowed to a sole discipline may not have proper solutions for issues facing the accounting profession. A general theory for financial accounting has not been developed, nor does it permit a substitution by theoretical foundations, even if they are workable in their disciplines. At the same time, it does not guarantee fruitful academic research outcomes. The Multi-dimensions matrix encompasses a multi-paradigmatic discipline and legitimizes its existence as such (see Riahi-Belkaoui, 1996; see also Belkaoui, 2004, ch. 10).

In the current era of developments in the accounting discipline, accounting theory is neglected in US academic accounting research (Al-Adeem \& Fogarty, 2010) and across the world; a noteworthy example is Nigeria (Osho \& Omolola, 2018). Accounting theory may even be lost or displaced in the present-day developments of 
accounting as a discipline and profession (Al-Adeem \& Fogarty, 2011). Apprehensions about the status of accounting as a discipline have risen (Demski, 2007; Fellingham, 2007) and have motivated some to bravely portend the demise of accounting for its failure to align with the decision-making utility of the twenty-first century (Lev \& Gu, 2016). Such claims are deemed radical and even unnecessary. To be sure, almost all proposed accounting theories assume that the fiduciary steward seeks to prevent asset loss. The most recent methodological attempt in accounting research represented by positive accounting and its reliance on agency theory is deemed a disappointment (Kaplan \& Ruland, 1991), urging the need for proceeding, contributing, and constructing on efforts of the golden age of accounting research (Gaffikkin, 1988) and enlightened by pre-classical accounting thinkers (Previts, 1980) to re-theorize corporate model with new and more real premises (A-Adeem, forthcoming). Accounting researchers and journals alike need to broaden the scope of other disciplines for knowledge importation (see Basu, 2012; Coetsee, 2010; Dyckman, 2016; Dyckman \& Zeff, 2015; Jeanjean \& Ramirez, 2009; Williams, 2001).

The emerging needs of the utility of ethics in accounting due to an unsettled environment in which accounting operates and the changes in science call for normative accounting theorization where ethics underline it philosophically, epistemologically, and methodologically (Rogowska, 2018). In a rapidly changing environment, any restriction to accounting definition stymies its role and function (Glauter \& Underdowen, 1974). The stimulus of economics has locked some of the critical possibilities open for accounting (Glautier as cited 1973 as cited in Glautier 1983: 65).

Accounting is profoundly deep-rooted in contextual factors such as a country's social, political, and economic environment, which supposedly need to be considered (Hellmann et al., 2010). Operationalizing "the accounting function...[as] to serve information needs within a particular cultural environment and... reflect related social, economic, political, and legal influences" (Berry, 1983, p. 137) [16], one would question the prospect of a narrowed approach and research program of the Rochester School of Accountancy.

Uncertainty about the nature of accounting prevails. That is, some scholars in the accounting discipline still argue that accounting is an art. However, accounting is likely a combination of science and art. A financial accounting theory encompassing both of these components would provide a more palatable addition to the accounting field. Thus, deciding whether a positive methodology is suitable or not is valid under the view that accounting is only science and not art. Scientific inquiries entail limitations in objectively measuring perceived truth (e.g., Al-Adeem, 2018). It can be argued that if the ingredients of accounting take account of dimensions of art, what is the point of attempting to implement a model designed only for a scientific field? 


\section{Endnotes:}

[1] According to the Dictionary of Qualitative Inquiry, research methodology takes account of "a theory of how the inquiry should proceed. It involves analysis of assumptions, principles, and procedures in a particular approach to inquiry (that, in turn, governs the use of a particular method" (Schwandt, 2001, p.161). The research method hence is included and is a part of the research methodology. Some researchers may use them interchangeably in their empirical work when labeling the research method section in their inquiry as a research methodology.

[2] For more about the influence of these two studies, see Ball and Brown (2013), Ball and Brown (2019), Brown (1989), Lev (1998).

[3] This question has been undertaking by Carduff (2010) to address using the annual reports of US Steel corporation as a case study. Also, see Carduff and Fogarty (2015).

[4] For a short introduction that briefly addresses agency in business ethics, philosophy, and law and a corporate setting, see Mansell, Ferguson, Gindis, and Pasternak (2019).

[5] Accounting literature contains studies prompting positive accounting authored by accounting researchers originally from Egypt, an African nation, published their work in journals sponsored by Saudi institutions probably while they were working in Saudi institutions, to expose their work, or for other reasons. This group of researchers includes for example, Alameen, (1997); Hassan (2014); Saraj, (1989).

[6] Al-Adeem and Fogarty (2010, p. 79) provide a history for this particular statement. They state, "It was first published when the Institute used to be named the American Institute of Accountants (AIA). In 1957, the name was changed to the American Institution of Certified Public Accountants (AICPA) (see http://www.aicpa.org). The statement was later reprinted several times (1959, 1963, 1968, 1974 and 1977) by the American Accounting Association." [7] Professor Gabriel A. D. Preinreich wrote extensively on accounting and accounting theory-related topics, but his fame and contribution have sorrowfully passed unrecognized. Brief (1966, xiii-xxiii) collected some of his contributions and shed light on some of his life. Some of the articles Professor Preinreich authored were collected in a volume edited by Professor Richard Brief and published in the Routledge Revivals series. A debt of gratitude is owed to Professor Richard Brief for noticing his contribution, and some of it has been compiled in a single volume and, most importantly, for writing the introduction about him. The introduction, in my opinion, is a significant contribution in the development of accounting thought literature as no articles written for his memorial are similar to what academics usually do when a colleague passes away. The book was reviewed by Bloom (1997).

[8] See Wyhe (1994) for the journey that accounting has taken to find its place in the college of businesses.

[9] Retrieved: https://academicworks.cuny.edu/cgi/viewcontent.cgi? article $=2075 \&$ context= bb_pubs last visit 6/21/2021

[10] Merino (1993) studies in a pragmatic fashion effort and contribution of early accounting theorists who are deemed, proprietary-theory advocates. Their concern of shareholders' property rights that the US constitution grants them is what drove early accounting theorists to advocate the preparation of a corporation's financial statements from the owner equity perspective. Studying their writings, Merino (1993) assures that they are no lesser pragmatic than others theorists who are deemed pragmatic.

Previts (2003, p. 276 emphasis added) portrays the role of the CPA profession in such an economy: 
Properly identified imaginary needs, an inaccurately proposed methodology:

The case of Rochester school of accountancy's positive accounting methodology

"Adapt our role in society to the recognition that today we serve a nation of investors, individual and institutional, in a far more fundamentally important way than we previously recognized. For the role which accountants play in providing capital markets information goes further than functioning as the "go between" identified in Berle and Means model of separation of ownership and control. Indeed our role goes to the heart of the constitutional right to own private productive property."

[11]As the editor of the Journal of Accounting Research, Dopuch (1979: 80) was proud to declare that, "Personally, I do believe that the traditional form of normative income theorizing is [dead], and I have done my best...to encourage this end."

[12] A philosophy is attributed to that Machiavelli documented in his book titled The Prince (1513). For a translation, see:

Machiavelli, N. (1995). The Prince [1513]. The Prince and other Political Writings, translated by W. K. Marriott. ed. S. Milner. The Pennsylvania State University

[13] Retrieved https://www.fox.temple.edu/about-fox/directory/dr-sudipta-basu/ <last visit 6/29/2021>

[14] Tinker and Puxty (1995:65-239) reproduced comments of Professor Paul Williams and Professor Germain Boer and others on the papers by Watts \& Zimmerman (1979) submitted to the editor of The Accounting Review, which is the AAA journal, at that time, Professor Stephan Zeff and the replies by Professor Ross Watts and Professor Jerold Zimmerman. The materials were analyzed to support the case that the production of accounting knowledge is policed and elites are keeping the gate of accounting knowledge guarded. The accounting literature documents yet another treatment by Accounting Horizons, an AAA journal, to commentary by Professor Abraham Brilof. What is so astonishing is the Abacus journal once published comments (Subotnik, 1991) on an article (Bricker, 1988) previously published in the journal. The comments were also accompanied by the author's reply (Bricker, 1991) of the reviewed article to the review. One finds the richness in the dialogue and observes vividly democracy responsible journal editors exercise and witness liberty in academe.

[15] For discussion on testing and significance in accounting research and related issues, see Dyckman (2016) and Dyckman and Zeff (2914; 2018; 2019); Kim, Ahmed \& Ji. (2018). Stone (2018). For general discussion on issues in testing and significance, see Ohlson, (2018); Gunst, \& Mason, (2018); van Dongen \& van Grootel (2021); Kim \& Robinson, 2019).

[16] Also see Al-Adeem, 2020; Gambling, 1974 and Riahi-Belkaoui, 1995 for cultural and societal aspects of accounting.

\section{References}

AdbulaHakam, A.Y. A. (2008) "Analyzing Fundamental of Positive Accounting Theory and Its Role in Building Standards and Selecting Among Alternatives: Analysis and Application", Master Thesis University of Um Dorman. Sudan.

Alameen, B. I. (1997) "Accounting choices from positive accounting theory perspective", Accounting, vol. 4. no. 12: 44-48.

Al-Adeem, K.R. (2017a) "A need to theorize corporations: An accounting perspective", International Journal of Accounting Research, vol. 5:166, doi: 10.4172/2472-114X.1000166 
Al-Adeem, K.R. (2017b) "Role of doctoral education in shaping minds and thinking: Reflection on my doctoral education at Case Western Reserve University". International Journal of Critical Accounting, vol. 9. no. 5-6: 494-513, doi: 10.1504/IJCA.2017.090578

Al-Adeem, K.R. (2017c) "Contributions of gulf Cooperation Council for Accounting and Auditing Organization's (GCCAAO) attempts unifying accounting practices and standards in enriching accounting thought: Analysis and evaluation", Accounting Thought Journal, vol. 21. no. (2): 533-566.

Al-Adeem, K. R. (2019a, March) "Book review of: Understanding Mattessich and Ijiri: A Study of Accounting Thought". European Accounting Association, EAA Newsletter. https://mailchi.mp/f9c88eb16bd9/eaa-newsletter-march2019-2\#Have\%20you\%20read

Al-Adeem, K. R. (2019b), "Who decides what is publishable? Empirical study on the influence of a journal's editorial board on the observed paradigm shift in US academic accounting research", The North American Accounting Studies, vol. 2. no.1: 1-21.

Al-Adeem, K. (2019c) "Critique and an Extension of Nohora Garcia's Understanding Mattessich and Ijiri: A Study of Accounting Thought", International Journal of Accounting and Financial Reporting, vol. 9. no.4: 420-438.

Al-Adeem, K. R. (2020) "Cultural challenges for countries implementing International Financial Reporting Standards without contributing to their creation". African Journal of Accounting, Auditing and Finance, vol. 97. no. 1: 66-86.

A-Adeem, K.R. (forthcoming) "Empirically Investigating the Presence of Positive Accounting Research as the Meta-Theory for Accounting Academics: Further Evidence from Saudi Arabia. Journal of Accounting and Management.

Al-Adeem, K. R. (forthcoming) "Reconceptualizing the management-auditor relationship by applying the general partnership contract to challenge independence: Ideals versus reality", Journal of Accounting, Business and Management.

Al-Adeem, K.R. \& Fogarty, T.J. (2010) Accounting Theory: A Neglected Topic in Academic Accounting Research. LAP Lambert Academic Publishing AG \& Co. KG.

Al-Hazzani, M. \& Al-Adeem, K.R. (2020) “Do corporations' annual reports address shareholders as proprietors? Evidence from Saudi Arabia", International Journal of Auditing and Accounting Studies", vol. 9. no.2: 175-192.

American Accounting Association. (1936) A Tentative Statement of Accounting Principles underlying Corporate Finance Statements, Reprinted in Accounting and Reporting Standards for Corporate Financial Statements and Preceding Statements and Supplements (pp. 59-64), Sarasota, FL: American Accounting Association. 
Properly identified imaginary needs, an inaccurately proposed methodology:

The case of Rochester school of accountancy's positive accounting methodology

American Accounting Association. (1941) Accounting Principles Underlining Corporate Financial Statements, Reprinted in Accounting and Reporting Standards for Corporate Financial Statements and Preceding Statements and Supplements (pp. 51-58), Sarasota, FL: American Accounting Association.

American Accounting Association. (1948) Principles Underlining Corporate Financial Statements, Reprinted in Accounting and Reporting Standards for Corporate Financial Statements and Preceding Statements and Supplements (pp. 13-18), Sarasota, FL: American Accounting Association.

American Accounting Association. (1957) Accounting Principles Underlining Corporate Financial Statements, Reprinted in Accounting and Reporting Standards for Corporate Financial Statements and Preceding Statements and Supplements (pp. 1-12), Sarasota, FL: American Accounting Association.

American Accounting Association. (1966), A Statement of Basic Accounting Theory (ASOBAT), Sarasota, FL: American Accounting Association.

American Accounting Association. (1971) Report of the committee on Accounting Theory Construction and Verification, Sarasota, FL: American Accounting Association.

Antle, R. \& Nalebuff, B. (1991) "Conservatism and auditor-client negotiations", Journal of Accounting Research, vol. 29: 31-54.

Avelé, D. (2014) "Positive accounting theory: theoretical and critical perspectives", International Journal of Critical Accounting, vol. 6. no.4: 396-415.

Ball, R. (1971) "Index of empirical research in accounting", Journal of Accounting Research, vol. 9. no.1: 1-31.

Ball, R. \& Brown, P. (1968) "An empirical evaluation of accounting income numbers", Journal of Accounting Research, vol. 9. no. 2: 156-178.

Ball, R. \& Brown, P. R. (2013) "Ball and Brown (1968): A Retrospective", The Accounting Review, vol. 89. no.1: 1-26.

Basu, S. (2012) "How can accounting researchers become more innovative?", Accounting Horizons, vol. 26. no 4: 851-870.

Basu, S. (2015) "Is there a scientific basis for accounting? Implications for practice, research, and education", Journal of International Accounting Research, vol. 14. No. 2: 235-265.

Beuren, I.M. \& de Souza, J. C. (2011) "Kuhn's theory of scientific revolution in accounting article", Corporate Ownership and Control, vol. 8. no. 2. 8(2): 77-88.

Beaver, W.H. (1968) "The information content of annual earnings announcements", Journal of Accounting Research. Supplement: 67-92.

Beaver, W.H. (1998) Financial Reporting: An Accounting Revolution ( $3^{\text {rd }}$ ed.), Upper Saddle River, NJ: Prentice Hall.

Beaver, W. (2002) "Review of the book Accounting Theory: An Information Content Perspective by John A. Christensen \& Joel S. Demski", European Accounting Review, vol. 11. no. 3: 631-633.

Bedford, N.M. (1965) Income Determination Theory: An Accounting Framework. Addison-Wesley. 
Belkaoui, A.R. (1996) Accounting, A Multiparadigm Science, Westport, CT: Quorum Books.

Belkaoui, A.R. (2004) Accounting Theory ( $5^{\text {th }}$ ed.), London: Thomson Learning.

Berle, A.A. \& Means, G.C. (1932) The Modern Corporation and Private Property, New York: Macmillan.

Bloom, R. (1997) "Richard P. Brief, A Landmark in Accounting Theory: The Work of Gabriel A. D. Preinreich", The Accounting Review, vol. 72. no. 1: 179-181.

Bloom, R, Heymann, H.G, Fuglister, J. \& Collins, M. (1994), The Schism in Accounting, Westport, CT: Quorum Books.

Boland, L.A. \& Gordon, I. M. (1992) "Criticizing positive accounting theory", Contemporary Accounting Research, vol. 9. No. 1: 142-170.

Brief, R. (1996) A landmark in Accounting Theory: The work of Gabriel AD Preinreich. In (Richard Brief ed.), Routledge: Taylor \& Francis.

Bricker, R.J. (1988) "Knowledge preservation in accounting: A citational study" Abacus, vol. 24. No. 2: 120-131.

Bricker, R.J. (1991) "The importance of history for accounting research". Abacus, vol. 27. no. 1: 72-77.

Bricker, R.J. (1993) Toward understanding academic research (accounting) The CPA Journal, vol. 63 no. 2: 52-54.

Bricker (2006) Doctoral Accounting Seminar in Contemporary Accounting Research. Weatherhead School of Management, Case Western Reserve University.

Bricker. R.J., \& Previts, G.J. (1990) "The sociology of accountancy: A study of academic and practice community schisms", Accounting Horizons, vol. 4. no. $1: 1-14$

Brown, P. (1989) "Invited remarks: Ball and Brown [1968]", Journal of Accounting Research Current Studies on The Information Content of Accounting Earnings, vol. 27: 202-217.

Carduff, K.C. (2010) Corporate reporting: From stewardship to contract the annual reports of the United States Steel Corporation (1902-2006) (Unpublished Doctoral Dissertation), Case Western Reserve University, https://uatetd.ohiolink.edu/ap/10?3326679126907::NO:10:P10_ETD_SUBID:52232.

Carduff, K.C. \& Fogarty, T.J. (2014) "Men of steel: Voluntary accounting information disclosure in the first third of the twentieth century at US Steel Corporation", Research in Accounting Regulation, vol.26. no. 2: 196-203. doi: 10.1016/j.racreg.2014.09.008.

Chatfield, M. (1975) "The Accounting Review's first fifty years”, The Accounting Review, vol. 50 no. 1: 1-6.

Chatfield, M. (1977) A History of Accounting Thought (Revised ed.), Huntington, New York: R.E. Krieger Pub. Co,

Chabrak, N. (2005) "The politics of transcendence: hermeneutic phenomenology and accounting policy", Critical Perspectives on Accounting, vol. 16. no. 2: 701-716. 
Chabrak, N., \& Burrowes, A. (2006) "The Language of the Rochester School: positive accounting theory Deconstructed", In $8^{\text {th }}$ IPA Conference, The Interdisciplinary Perspectives on Accounting Conference.

Chambers, R.J. (1976) "The possibility of a normative accounting standard", The Accounting Review, vol. 51. no. 3: 646-652.

Chalmers, A. F. (1999), What Is This Thing Called Science? ( $3^{\text {rd }}$ ed.) Indianapolis, IN: Hackett Publishing Company, Inc.

Chambers, R.J. (1993) "Positive accounting theory and the PA cult", Abacus, vol.29. no. $1: 1-26$.

Christenson, C. (1983) "Methodology of positive accounting", The Accounting Review, vol.58. no.1: 1-22.

Cloete, N., \& Maassen, P. \& Bailey, T. (2015) Knowledge Production and Contradictory Functions in African Higher Education, African Minds.

Cohen, J. R., Holder-Webb, L., Sharp, D. J., \& Pant, L.W. (2007) "The effects of perceived fairness on opportunistic behavior", Contemporary Accounting Research, vol. 24/ no.4: 1119-1138.

Collin, S. O. Y., Tagesson, T., Andersson, A., Cato, J., \& Hansson, K. (2009), "Explaining the choice of accounting standards in municipal corporations: Positive accounting theory and institutional theory as competitive or concurrent theories", Critical perspectives on Accounting, vol. 20. no 2: 141-174.

Coetsee, D. (2010) "The role of accounting theory in the development of accounting principles" Meditari Accountancy Research, vol.18. no.1: 1-16.

Conway, R. (2020) The Truth about Public Accountants, Robert: Books

Cowan, T. K. (1968) "A pragmatic approach to accounting theory", The Accounting Review, vol. 43 no. 1: 94-100.

Cushing, B.E. (1989) "A Kuhnian interpretation of the historical evolution of accounting”, Accounting Historians Journal, vol. 16. no. 2: 1-41.

Dopuch, N. (1979) "Empirical vs. non-empirical contributions to accounting theory development", in J.J. Davis (ed.) pp. 67-83, Accounting Research Convocation on the Subject of Seeking Full Disclosure, University of Alabama.

Demski, J.S. (1988) "Positive accounting theory: A review", Accounting, Organizations and Society, vol. 13. no. 6: 623-629.

Dyckman, T.R. (2016) "Significance testing: We can do better". Abacus, vol. 52. no. 2: 319-342.

Dyckman, T.R. \& Zeff, S.A. (2014) "Some methodological deficiencies in empirical research articles in accounting", Accounting Horizons, vol. 28. no. 3: 695-712.

Dyckman, T.R. \& Zeff, S. A. (2015) "Accounting research: past, present, and future", Abacus, vol. 51. no. 4: 511-524.

Dyckman, T. R. \& Zeff., S.A. (2018) "Methodological deficiencies of null hypothesis statistical tests in regression analysis", Abacus. vol. 28. no. 3: 695-712. 
Dyckman, T. R. \& Zeff. S. A. (2019) "Important issues in statistical testing and recommended improvements in accounting research", Econometrics, vol. 7. no. 2: 1-11.

Fama, E. F. \& Jensen. M. C. (1983), "Separation of ownership and control”, The Journal of Law and Economics, vol. 26. no. 2: 301-325.

Farjaudon, A. L. \& Morales, J. (2013) "In search of consensus: The role of accounting in the definition and reproduction of dominant interests", Critical Perspectives on Accounting, vol. 24. no. 2: 154-171.

Fellingham, J.C. (2007) "Is accounting an academic discipline?" Accounting Horizons. vol. 21. no. 2: 159-163. doi:10.2308/acch.2007.21.2.159.

Feyerabend, P. (2010) Against Method: Outline of an Anarchistic Theory of Knowledge, $4^{\text {th }}$ ed., New Edition Introduced by Ian Hacking, London, UK: Verso.

Findlay, M. C. \& Williams, E. E. (1987) "Toward a positive theory of corporate financial policy", Abacus, vol. 23 no. 2: 107-121.

Fogarty, T. J. (2011) The social construction of research advice: The American Accounting Association plays Miss Lonelyhearts, "Accounting and the Public Interest", 11(1), s. 32-51.

Fogarty, T. \& Jonas, G. (2010) "The hand that rocks the cradle: Disciplinary socialization at the American Accounting Association's Doctoral Consortium", Critical Perspectives on Accounting. vol. 21 no. 4: 303-317.

Fogarty, T. J. \& Jonas, G.A. (2013) "Author characteristics for major accounting journals: Differences among similarities 1989-2009", Issues in Accounting Education, vol. 28. no. 4: 731-757.

Fogarty, T. J. \& Liao, C. (2009) "Blessed are the gatekeepers: A longitudinal study of the editorial boards of The Accounting Review", Issues in Accounting Education, vol. 24. no. 3: 299-318.

Fogarty, T. J. \& Zimmerman, A. (2019) "Few are called, fewer are chosen: Elite reproduction in US academic accounting", Critical Perspectives on Accounting, vol. 60: 1-17.

Flesher, D. L. (1991) The Third-Quarter Century of the American Accounting Association: 1966-1991, Sarasota, FL: American Accounting Association.

Foster, G. (1988) "Leveraging the three sisters of production: Research, practice and teaching", In Plenary Address at Annual Meeting of American Accounting Association. August, Orlando, Florida.

Friedman, M. (1953) "The economics of positive methodology", Essays on Positive Economics. University of Chicago Press, Chicago.

Gaffikin, M.J.R. (1987) "The methodology of early accounting theorists", Abacus, vol. 23. no. 1: 17-29.

Gaffikin, M.J. (1988) "Legacy of the golden age: Recent developments in the methodology of accounting", Abacus, vol. 24. no. 1: 16-36.

Gambling, T. (1974) Societal Accounting. Allen and Unwin.

Gioia, D.A., Pitre, E. (1990) "Multiparadigm perspectives on theory building", Academy of Management Review, vol. 15. no. 4: 584-602. 
Properly identified imaginary needs, an inaccurately proposed methodology:

The case of Rochester school of accountancy's positive accounting methodology

Gibbins, M., Salterio, S., \& Webb, S. (2001) "Evidence About auditor-client management negotiation concerning client's financial reporting", Journal of Accounting Research, vol. 39. no. 3: 535-563.

Glautier, M. W. (1983) Searching for accounting paradigms", The Accounting Historians Journal, vol. 10. no. 1: 51-68.

Grady, P. (1965) Inventory of Generally Accepted Accounting Principles for Business Enterprises (ARS. 7), American Institute of Certified Public Accountants. Accounting Research Division.

Granof, M. H. \& Zeff, S.A. (2008) "Research on accounting should learn from the past", The Chronicle of Higher Education, vol. 54. no. 28: A34.

García, N. (2017), Understanding Mattessich and Ijiri: A study of accounting thought. Emerald Publishing.

Gordon, R.A. \& Howell, J.E. (1959) Higher Education for Business, New York: Columbia University Press

Grebe, L., Odendaal, E. (2017) "Accounting research, education and practice: A social practice theory perspective", Southern African Journal of Accountability and Auditing Research, vol. 19. no. 1: 147-156.

Gunst, R.F. \& Mason, R.L. (2018) Regression Analysis and Its Application: A DataOriented Approach, CRC Press.

Hackenbrack, K. \& Nelson, M.W. (1996) “Auditors' incentives and their application of financial accounting standards", The Accounting Review. vol. 71 no. 1: 4359.

Hassan, N. T. (2014) "Determines of accounting choices in Saudi public companies", Egyptian Accounting Review. vol. 4. no. 8: 73-107.

Heck, J. \& Jensen, B. (2007) "An analysis of the evolution of research contributions by The Accounting Review, 1926-2005", Accounting Historians Journal, vol. 34. no. 2: 109-142.

Hellmann, A., Perera, H. \& Patel, C. (2010) "Contextual issues of the convergence of International Financial Reporting Standards: the case of Germany", Advances in Accounting, vol. 26. no. 1: 108-116.

Hines, R.D. (1988) "Popper's methodology of falsificationism and accounting research", The Accounting Review, vol. 63. no. 4: 657-662.

Holthausen, R.W. (1990) "Accounting method choice: Opportunistic behavior, efficient contracting, and information perspectives", Journal of Accounting and Economics, vol. 12. no. 1-3: 207-218.

Hopwood, A.G. (1987) "The archeology of accounting systems", Accounting, Organizations and Society, vol. 12. no. 3: 207-234.

Horngren, C.T. (1981) "Uses and limitations of a conceptual framework", Journal of Accountancy, vol. 151. no 4: 86.

Hunt III, H. G., \& Hogler, R. L. (1990) "Agency theory as ideology: A comparative analysis based on critical legal theory and radical accounting", Accounting, Organizations and Society, vol. 15. no. 5: 437-454.

Ibraheem, A.A M. (2002) Accounting Theory. 
Ibraheem, A.A.M. (2008) "Evaluating traditional and modern research approaches in contracting accounting theory", Contemporary Commercial Research Journal, vol. 22. no. 1: 50-85.

Jensen, M. C. \& Meckling, W.H. (1976) "Theory of the firm: Managerial behavior, agency costs and ownership structure", Journal of Financial Economics, vol. 3. no. 4: 305-360.

Ijiri, Y. (1967) The Foundations of Accounting Measurement: A Mathematical, Economic, and Behavioral Inquiry. Prentice-Hall.

Ijiri, Y. (1975), Theory of Accounting Measurement (No. 10) Sarasota, FL: American Accounting Association

Inanga, E. L. \& Schneider, W.B. (2005) "The failure of accounting research to improve accounting practice: a problem of theory and lack of communication", Critical Perspectives on Accounting, vol. 16. no. 3: 227-248.

Jeanjean, T. \& Ramirez, C. (2009) "Back to the origins of positive theories: A contribution to an analysis of paradigm changes in accounting research", Accounting in Europe, vol. 6. no. 1: 107-126.

Kabalski, P. (2016) "Why should accounting science be more normative?" Zeszyty Teoretyczne Rachunkowości, vol. 88: 61-72.

Kabir, H. (2010) "Positive accounting theory and science", Journal of Centrum Cathedra, vol. 3. no. 2: 136-149

Kaplan, R.S. (1989) "Connecting the research-teaching-practice triangle", Accounting Horizons, vol. 3. no. 1: 129.

Kaplan, S.E. \& Ruland, R.G. (1991) "Positive theory, rationality and accounting regulation", Critical Perspectives on Accounting. vol. 2. no. 4: 361-374.

Kim, J. H., Ahmed, K., \& Ji, P.I. (2018) "Significance testing in accounting research: A critical evaluation based on evidence", Abacus, vol. 54. no. 4: 524-546.

Kim, J. H. \& Robinson, A.P. (2019) "Interval-based hypothesis testing and its applications to economics and finance", Econometrics, vol. 7. no. 2: 21.

King, T.A. (2006) More than a numbers game: A brief history of accounting, John Wiley \& Sons.

Kothari, S.P. (2001) "Capital markets research in accounting", Journal of Accounting and Economics, vol. 31. no. 1-3: 105-231.

Kuhn, T. S. (1996) The Structure of Science Revolution ( $3^{\text {rd }}$ ed.), Chicago, IL: The University of Chicago Press.

Laudan, L. (1981) A problem-solving approach to scientific progress, in I. Hacking (Ed.) Scientific Revolutions. Pp. 144-155, Oxford University Press.

Laughlin, R.C. (1981) "On the nature of accounting methodology", Journal of Business Finance and Accounting, vol. 8. no. 3: 329-351.

Lughlin, R. C. \& Puxty, (1981) "The decision usefulness criterion: Wrong cart wrong horse?" The British Accounting Review, vol. 13. no. 1:43-87.

Lee, T.A. (2009) "Financial accounting theory", In J.R. Edwards, \& S.P. Walker (Eds.), The Routledge Companion to Accounting Theory. (pp. 139-161) Routledge Taylor \& Francis Group. 
Properly identified imaginary needs, an inaccurately proposed methodology:

The case of Rochester school of accountancy's positive accounting methodology

Lee, P., Guthrie., J. \& Gray, R. (1998) "Accounting and management research: Passwords from the gatekeepers", Accounting, Auditing \& Accountability Journal, vol. 11. no. 4: 371-406.

Lee, T. (1989) "Education, practice and research in accounting: gaps, closed loops, bridges and magic accounting", Accounting and Business Research, vol. 19. no. 75: 237-253.

Lee, T. (1995) "Shaping the US academic accounting research profession: The American Accounting Association and the social construction of a professional elite", Critical Perspectives on Accounting, vol. 6. no. 3: 241-261.

Lee, T. (1997) "The editorial gatekeepers of the accounting academy", Accounting, Auditing \& Accountability Journal, vol. 10. no. 1: 11-30.

Lee, T (1999) "Anatomy of professional elite: The executive committee of the American Accounting Association 1916-1996", Critical Perspectives on Accounting, vol. 10. no. 2: 247-264.

Lee, T.A. (2001) "Sustaining a habitus", In Advances in Accountability: Regulation, Research, Gender and Justice CR Lehman (Ed.) (pp. 177-194. (Advances in Public Interest Accounting, 8), Emerald Group Publishing Limited, Bingley.

Lee, T. (2006a) The FASB and accounting for economic reality. Accounting and the Public Interest, vol. 6: 1-21.

Lee, T. (2006a) "Reply to commentary: The FASB and accounting for economic reality. Cunning plans, spinners, and ideologues: Blackadder and Baldrick try accounting for economic reality", Accounting and the Public Interest, vol. 6: 45-50.

Lee, T. \& Williams, P. (1999) "Accounting from the inside: Legitimating the accounting academic elite", Critical Perspectives on Accounting, vol. 10. no.6: 867-895.

Lev, B. (1998) "On the usefulness of earnings and earnings research: Lessons and directions from two decades of empirical research. Journal of Accounting Research", Current Studies on the Information Content of Accounting Earning, vol. 27: 153-192.

Lev, B. \& Gu, F. (2016) The End of Accounting and the Path Forward for Investors and Managers, John Wiley \& Sons.

Littleton, A.C. (1933/1981) Accounting Evolution to 1900, Reprinted Academy of Accounting Historians.

Lowe, E. A., Puxty, A.G., \& Laughlin, R.C. (1983) "Simple theories for complex processes: Accounting policy and the market for myopia", Journal of Accounting and Public Policy. vol 2. no. 1: 19-42.

Macintosh, N. B. T. (2006) "Accounting-Truth, lies, or "bullshit? A philosophical investigation", Accounting and the Public Interest. 6: 22-36.

Mattessich, R. V. (2009) "FASB and social reality-An alternate realist view", Accounting and the Public Interest, vol. 9. no. 1: 39-64.

Major, M. J. (2017) "Positivism and "alternative" accounting research", Revista Contabilidade \& Finanças, vol. 28. no. 74: 173-178. 
Mansell, S., Ferguson, J., Gindis, D., \& Pasternak, A. (2019) "Rethinking corporate agency in business, philosophy, and law", Journal of Business Ethics, vol. 154: 893-899

May, G. O. (1943) "The nature of the financial accounting process", The Accounting Review, vol. 18. no. 3: 189-193.

Merino, B.D. (1993) "An analysis of the development of accounting knowledge: A pragmatic approach", Accounting, Organizations and Society, vol. 18. no. 2/3: 163-185. doi: 10.1016/0361-3682(93)90032-2

Moonitz, M. (1961) The Basic Postulates of Accounting (ARS. No. 1) American Institute of Certified Public Accountants, Accounting Research Division.

Mostafay, S.H. (1991) "Evaluating positive accounting theory in building financial accounting standards from agency theory perspective", Accounting, Management and Finance Journal, vol. 32. no 43: 67-108.

Mouck, T (1989) "Irony of the golden age of accounting methodology", Accounting Historians Journal, vol. 16. no. 2: 3.

Mouck, T. (1990) "Positive accounting theory as a Lakatosian research programme", Accounting and Business Research, vol. 21. no. 79: 231-239.

Mouck, T. (1992) "The rhetoric of science and the rhetoric of revolt in the "story" of positive accounting theory" Accounting, Auditing \& Accountability Journal, vol. 5. no. 4: 35-56.

Mouck, T. (1993) "The "Revolution" in financial reporting theory: A Kuhnian interpretation", Accounting Historians Journal, vol. 20. no. 1: 33-57.

Nasution, S. T. A., Putri, R. F., Muda, I., \& Ginting, S. (2020) "Positive accounting theory: Theoretical perspectives on accounting policy choice", Proceedings of the 1st Unimed International Conference on Economics Education and Social Science (UNICEES 2018): 1128-1133

Milne, M. J. (2002) "Positive accounting theory, political costs and social disclosure analyses: a critical look", Critical Perspectives on Accounting. 13(3): 369395.

Ndjetcheu, L. (2012) "An African critical interpretation of the positive theory of accounting of Watts and Zimmerman (1978, 1980, 1986)", African Journal of Accounting, Auditing and Finance, vol. 1. no 1:25-39.

Nurnberg, H. (2015) "Changing perceptions of US standard setters concerning the basic objectives of corporate financial reporting", Accounting Historians Journal, vol. 42. no. 1: 61-83.

Ohlson, J.A. (2018) Researchers' Data Analysis Choices: An Excess of False Positives?, doi: 10.2139/ssrn.3089571

Okcabol, F. \& Tinker, T. (1990) "The market for positive theory: deconstructing the theory for excuses", Advances in Public Interest, vol. 3: 71-95.

Osho, A.E. \& Omolola, R.A. (2018) "Exploring the neglect of accounting theory in current academic research in Nigeria", European Scientific Journal, vol. 14. No. 25: 156-168. doi: 10.19004/esj.2018.v14n25p156. 
Properly identified imaginary needs, an inaccurately proposed methodology:

The case of Rochester school of accountancy's positive accounting methodology

Osho, A.E. \& Ayorinde, F.M. (2018) "The General Tenets of Positive Accounting Theory Towards Accounting Practice and Disclosure in Corporate Organizations in Nigeria", Journal of Economics and Sustainable Development, vol. 9. no. (20): 1-11.

Othamn, A.I. (2000) "Evaluating the scientific methodology for the conceptual framework of positive accounting theory", Public Administration, vol. 39. no. 4: 729-772.

Paton, W.A. (1922), Accounting Theory, with Special Reference to the Corporate Enterprise, Ronald Press.

Petruk, O. M., Legenchuk, S.F. \& Koroliuk, N.M. (2013) "Development of accounting theory in English-speaking countries: On the way to multiparadigmatic discipline", Облік і фінанси, vol. 3: 48-56.

Persson, M. E. (Ed.) (2016) AC Littleton's Final Thoughts lon Accounting: A collection of Unpublished Essays, Foreword, Emerald Group Publishing Limited.

Pierson, F.C. (1959) The Education of American Businessmen: A study of UniversityCollege Programs in Business Administration, New York: McGraw-Hill.

Preinreich, G.A. (1996) A landmark in Accounting Theory: The work of Gabriel AD Preinreich (Richard Brief ed.), London: Routledge, Taylor \& Francis.

Previts, G.J. (1980), A Critical Evaluation of Comparative Financial Accounting Thought in America, 1900 to 1920, New York: Arno Press

Previts, G.J. (1984) "Methods and meanings of historical interpretation for accountancy", Accounting Historians Notebook. vol. 7. no. 2: 13-19.

Previts, G.J. (2003) "The "Information Right" and the CPA profession", Research in Accounting Regulation, vol. 16: 275-277.

Previts, G.J. \& Merino, B.D. (1998) A History of Accountancy in the United States, Ohio: Ohio State University Press.

Quinn Jr, E. (2014) "The evolution of accounting theory in response to market changes", International Journal of Academic Research in Business and Social Sciences. vol. 4. no. 10: 509-518.

Reiter, S.A. (1998) "Economics imperialism and the crisis in financial accounting research", Critical Perspectives on Accounting, vol. 9: 143-171.

Reiter, S.A. \& Williams, P.F. (2004) "The philosophy and rhetoric of auditor independence concepts", Business Ethics Quarterly, vol. 14. no. 3: 355-376.

Riahi-Belkaoui, A. (1995) The Cultural Shaping of Accounting. Westport CT: Greenwood Publishing Group.

Riahi-Belkaoui, A. (1996) Accounting, a Multiparadigmatic Science. Westport CT: Greenwood Publishing Group.

Roe, M.J. (1996) Strong Managers, Weak Owners: The Political Roots of American Corporate Finance, Princeton, NJ: Princeton University Press.

Rogowska, B. (2018) "Ethical aspects of normative theories of accounting", Annales. Etyka w Życiu Gospodarczym, vol. 21. no. 8: 17-29.

Rutherford, B.A. (2011) "Accounting research and accounting policy: what kind of gap?", Accounting in Europe, vol. 8. no. 2: 141-154. 
Sanders, T. H., Hatfield, H.R. \& Moore, U. (1938) A Statement of Accounting Principles. American Institute of Certified Public Accountants, Accounting Research Division.

Saraj, M.A. (1989) "Analysis of the effectiveness of using normative approach and positive approach in accounting theorization", Public Administration, vol. 63. no. 1: 143-176.

Schulze, W.S., Lubatkin, M.H., Dino, R.N. \& Buchholtz, A. K. (2001) "Agency relationships in family firms: Theory and evidence", Organization Science, vol. 12. no. 2: 99-116.

Shearer, T. (2002) "Ethics and accountability: from the for-itself to the for-theother", Accounting, Organizations and Society, vol. 27. no. 6: 541-573.

Schiehll, E., Borba, J.A. \& Murcia, F.D.R. (2007) "Financial accounting: an epistemological research note", Revista Contabilidade \& Finanças, vol. 18. no. 45: 83-90.

Schroeder, R.G., Clark, M.W. \& Cathey, J.M. (2010) Financial Accounting Theory and Analysis ( $7^{\text {th }}$ ed. $)$, New York: John Wiley \& Sons, Inc.

Schwandt, T.A. (2001) Dictionary of Qualitative Inquiry ( $2^{\text {nd }}$ ed), New York: Sage publications.

Sinha, S.K. (2008) "Positive accounting theory: A critique", The IUP Journal of Accounting Research and Audit Practices, vol. 7. no. 4: 7-16.

Sorter, G. H. (1979) Beyond emptiness and blindness: Is there a hope for accounting research?, The Saxe Lectures in Accounting Series. New York University, https://academicworks.cuny.edu/cgi/viewcontent.cgi $?$ article=2088\&context= bb_pubs

Sprouse, R.T. \& Moonitz, M. (1962) A Tentative Set of Broad Accounting Principles for Business Enterprises (ARS. No. 3) American Institute of Certified Public Accountants, Accounting Research Division.

Staff of the Accounting Research Division. (1963) Reporting the Financial Effects of Price-Level Changes (ARS.6) American Institute of Certified Public Accountants.

Srivastava, J. \& Baag, P.K. (2020) "Positive accounting theory and agency costs: A critical perspective", AIMS International, vol. 2: 101-113

Statement on Accounting Theory and Theory Acceptance (SATTA) (1977) American Accounting Association Committee on Concepts and Standards for Externals Financial Reports, Sarasota, FL: American Accounting Association.

Sterling, R.R. (1973) "Accounting research, education and practice", Journal of Accountancy, vol. 136. no 3: 44.

Sterling, R.S. (1977) “Accounting in the 1980s. In. M. Bedford (ed.)", Some Issues: Proceedings of the Arthur Young Professors Roundtable: 225-268.

Sterling, R.R. (1988) "Confessions of a failed empiricist", Advances in Accounting, vol. 6: 3-35.

Sterling, R. S. (1990) "Positive accounting theory: An assessment”, Abacus, vol. 26. no. 2: $97-135$. 
Properly identified imaginary needs, an inaccurately proposed methodology:

The case of Rochester school of accountancy's positive accounting methodology

Stevelman, F. (2013) "Myths about shareholder value", Accounting Economics and Law: A Convivium, vol. 3. no. 1: 1-14. doi: 10.1515/ael-2013-0005

Stout, L.A. (2012) The Shareholder Value Myth: How Putting Shareholders First Harms Investors, Corporations, and the Public, San Francisco, CA: BerrettKoehler.

Stone, D.N. (2018) "The "new statistics" and nullifying the null: Twelve actions for improving quantitative accounting research quality and integrity", Accounting Horizons, vol. 32. no. 1: 105-120.

Subotnik D. (1991) "Knowledge Preservation in Accounting, Does It Deserve to be Preserved?", Abacus, vol. 27. no. 1: 65-71.

Sun, L., Rath, S. (2008) "Fundamental determinants, opportunistic behavior and signaling mechanism: An integration of earnings management perspectives", International Review of Business Research Papers, vol. 4. no. 4: 406-420.

Sy, A., \& Tinker, T. (2005) "Archival research and the lost worlds of accounting", Accounting History, vol. 10. no.1: 48-69.

Sy, A. \& Tinker, T. (2011) "From Mellmott to Madoff: history in the (re)making", Accounting Historians Journal, vol. 38. no. 1: 141-158.

The American Institute of Accountants (AIA) (1938), The American Institute of Accountants [1887-1937]: Fiftieth Anniversary Celebration, October Eighteenth to Twenty-Second New York City (Reprinted), Concord, NH: Rumford Press.

Tinker, T. (1988) "Panglossian accounting theories: the science of apologising in style", Accounting, Organizations and Society, vol. 13. no. 2: 165-189.

Tinker, A.M., Merino, B.D. \& Neimark, M. D. (1982) "The normative origins of positive theories: Ideology and accounting thought", Accounting, Organizations and Society, vol. 7. no. 2: 167-200.

Tinker, T. \& Puxty, T. (1995) Policing Accounting Knowledge: The Market for Excuses Affair, Princeton, NY: Markus Weiner Publishers.

Tuttle, B., \& Dillard., J. (2007) "Beyond competition: Institutional isomorphism in the U.S. accounting research", Accounting Horizons, vol. 21. no. 4: 387-409.

van Dongen, N. \&van Grootel, L. (2021) Overview on the Null Hypothesis Significance Test, Working paper.

Vatter, W. J. (1947) The Fund Theory of Accounting and Its Implications for Financial Reports, Chicago, IL: University of Chicago Press.

Volkova, O.N. (2018) "Accounting as an academic discipline: Paradigmatic limits and research programs", (December 1), https://ssrn.com/abstract $=3294658$

Watts, R. (1974) “Accounting objectives". Working paper series No. 7408. University of Rochester.

Watts, R.L. (1977) "Corporate financial statements, a product of the market and political processes", Australian Journal of Management, vol. 2. no. 1: 53-75.

Watts, R. (1983) The evolution of economics-based empirical research in accounting. The SAXE Lecture in Accounting. Retrieved: https://academicworks.cuny.edu/cgi/viewcontent.cgi?article=2075\&context= bb_pubs 
Watts, R.L. \& Zimmerman, J.L. (1978) "Toward positive accounting theory for the determination of accounting", The Accounting Review, vol. 53. no. (1): 112-134.

Watts, R.L. \& Zimmerman, J.L. (1979) The demand for and supply of accounting theories: the market for excuses", The Accounting Review. vol. 54. no. 2: 273-304.

Watts, R.L \& Zimmerman, J.L. (1981) "The Markets for Independence and Independent Auditors", Working paper series No. GPB/80-10, University of Rochester. Retrieved: https://urresearch.rochester.edu/institutional PublicationPublicView.action?institutionalItemId $=4475$

Watts, R.L \& Zimmerman, J.L. (1982) "Auditors and the Determination of Accounting Standards", Working paper series No. GPB / 78-06. University of Rochester. Retrieved: https://urresearch.rochester.edu/institutional PublicationPublicView.action?institutionalItemId $=4512$

Watts, R.L. \& Zimmerman, J.L. (1983) "Agency problems, auditing, and the theory of the firm: Some evidence", The Journal of Law and Economics, vol. 26. no. 3: 613-633.

Watts, R.L. \& Zimmerman, J.L. (1986) Positive Accounting Theory, New Jersey: Prentice-Hall.

Watts, R.L. \& Zimmerman, J.L. (1990) "Positive accounting theory: A ten year perspective", The Accounting Review, vol. 65. no. 1: 131-156.

Weinstein, O. (2013) "The shareholder model of the corporation, between mythology and reality", Accounting Economics and Law: A Convivium, vol. 3. no. 1: 43-60. doi: 10.1515/ael-2013-0032.

Wells, K. (2005) A Lecture on Qualitative Models. Ph. D. Course. Mandal School of Applied Social Science, Case Western Reserve University, Cleveland, Ohio: United States of America.

Wells, M. C. (1976) “A revolution in accounting thought?" The Accounting Review. 51(3), 471-482.

West, B.P. (2003) Professionalism and Accounting Rules, New York, NY: Routledge.

Whitley, R.D. (1988) "The possibility and utility of positive accounting theory", Accounting, Organizations and Society, vol. 13. no. 6: 631-645.

White, G. I., Sondhi, A.A. \& Fried, D. (2003) The Analysis and the Use of Financial Statements ( $3^{\text {rd }}$ edition), Hoboken, NJ: John Wiley \& Sons, Inc.

Whitley, R. (2000) The Intellectual and Social Organization of the Science (2 $2^{\text {nd }}$ ed) New York: Oxford University Press.

Whittington, G. (1987) "Positive accounting: A review article", Accounting and Business Research, vol. 17. no. 68: 327-336.

Williams, P.F. (1985) "A descriptive analysis of authorship in The Accounting Review", The Accounting Review, vol. 60. no. 2: 300-313.

Williams, P. F. (1989) "The logic of positive accounting theory", Accounting, Organizations and Society, vol. 14. no. 5/6): 455-468. 
Properly identified imaginary needs, an inaccurately proposed methodology:

The case of Rochester school of accountancy's positive accounting methodology

Williams, P.F. (2001) "Who gets to speak and what must they say? A commentary on the Briloff affair", Critical Perspectives on Accounting, vol. 12. no. 2: 213-219.

Williams, P.F. (2003) "Modern accounting scholarship: The imperative of positive economics science", Accounting Forum, vol. 27. no. 3: 251-269.

Williams, P. F. (2006) "Accounting for economic reality: Whose reality, which justice?", Accounting and the Public Interest, vol. 6: 37-44.

Williams, P. F. (2017) "Jumping on the wrong bus: Reflections on a long, strange journey", Critical Perspectives on Accounting, vol. 49: 76-85.

Williams, P.F. \& Ravenscroft, S.P. (2015) "Rethinking decision usefulness", Contemporary Accounting Research. vol. 32. no. 2: 763-788.

Wolk, H.I., Dodd, J.L., \& Tearney, M.G. (2004) Accounting Theory: Conceptual Issues in A Political and Economic Environment (6 ${ }^{\text {th }}$ ed.) Mason, $\mathrm{OH}$ : Thomson South-Western.

Wyhe, G.V. (1994) The Struggle for Status, New York, NY: Garland Publishing, Inc.

Yousof, A.M. (2006) "Analyses and critique the foundation of positive theorization in accounting", Business Administration, vol. 112: 26-35.

Yu, S.C. (1976) The Structure of Accounting Theory, Gainesville, FL: The University of Florida.

Zeff, S. (1966) The American Accounting Association: Its First 50 Years, Sarasota, FL: American Accounting Association.

Zeff, S.A. (1999) "The evolution of the conceptual framework for business enterprises in the United States", Accounting Historians Journal, vol. 26. no. 2: 89-131. 